Louisiana State University

LSU Digital Commons

Faculty Publications

Department of Oceanography \& Coastal

Sciences

8-8-2014

Carbon Dynamics On The Louisiana Continental Shelf And Cross-

Shelf Feeding Of Hypoxia

Brian Fry

Dubravko Justic

Philip Riekenberg

Erick M. Swenson

R. Eugene Turner

See next page for additional authors

Follow this and additional works at: https://digitalcommons.Isu.edu/oceanography_coastal_pubs 


\section{Authors}

Brian Fry, Dubravko Justic, Philip Riekenberg, Erick M. Swenson, R. Eugene Turner, Lixia Wang, Lora Pride, Nancy N. Rabalais, Janis C. Kurtz, John C. Lehrter, Michael c. Murrell, Elizabeth H. Shadwick, and Brandon Boyd 


\title{
Carbon Dynamics on the Louisiana Continental Shelf and Cross-Shelf Feeding of Hypoxia
}

\author{
Brian Fry • Dubravko Justić • Philip Riekenberg • Erick M. Swenson • R. Eugene Turner • \\ Lixia Wang • Lora Pride • Nancy N. Rabalais • Janis C. Kurtz • John C. Lehrter • \\ Michael C. Murrell • Elizabeth H. Shadwick • Brandon Boyd
}

Received: 25 February 2013 /Revised: 23 June 2014 / Accepted: 19 July 2014 / Published online: 8 August 2014

(C) Coastal and Estuarine Research Federation 2014

\begin{abstract}
Large-scale hypoxia regularly develops during the summer on the Louisiana continental shelf. Traditionally, hypoxia has been linked to the vast winter and spring nutrient inputs from the Mississippi River and its distributary, the Atchafalaya River. However, recent studies indicate that much of the shelf ecosystem is heterotrophic. We used data from five late July shelfwide cruises from 2006 to 2010 to examine carbon and oxygen production and identify net autotrophic areas of phytoplankton growth on the Louisiana shelf. During these summer times of moderate river flows, shelfwide $\mathrm{pH}$ and particulate organic carbon (POC) consistently showed strong signals for net autotrophy in low salinity $(<25)$ waters near the river mouths. There was substantial POC removal via
\end{abstract}

Communicated by Ken Dunton

B. Fry • D. Justić • P. Riekenberg • E. M. Swenson • R. E. Turner L. Wang

Department of Oceanography and Coastal Sciences, Louisiana State University, Baton Rouge, LA 70803, USA

B. Fry $(\bowtie)$

Australian Rivers Institute, Griffith University, 170 Kessels Road, Nathan, Brisbane, QLD 4111, Australia

e-mail: b.fry@griffith.edu.au

L. Pride $\cdot$ N. N. Rabalais

Louisiana Universities Marine Consortium, Chauvin, LA 70344, USA

J. C. Kurtz $\cdot$ J. C. Lehrter $\cdot$ M. C. Murrell

Gulf Ecology Division, US Environmental Protection Agency, 1

Sabine Island Drive, Gulf Breeze, FL 32561, USA

E. H. Shadwick

Virginia Institute of Marine Science, POB 1346, Gloucester Point, VA 23062-1346, USA

B. Boyd

College of the Earth, Ocean and Environment, University of

Delaware, 700 Pilottown Rd, Lewes, DE 19958, USA grazing and sedimentation in near-river regions, with 66-85\% of POC lost from surface waters in the low and mid-salinity ranges without producing strong respiration signals in surface waters. This POC removal in nearshore environments indicates highly efficient algal retention by the shelf ecosystem. Updated carbon export calculations for local estuaries and a preliminary shelfwide carbon budget agree with older concepts that offshore hypoxia is linked strongly to nutrient loading from the Mississippi River, but a new emphasis on cross-shelf dynamics emerged in this research. Cross-shelf transects indicated that river-influenced nearshore waters $<15 \mathrm{~m}$ deep are strong sources of net carbon production, with currents and wave-induced resuspension likely transporting this POC offshore to fuel hypoxia in adjacent mid-shelf bottom waters.

Keywords Hypoxia - Continental shelf · Budgets · POC . DIC $\cdot$ Net ecosystem metabolism

\section{Introduction}

The Mississippi River is one of the world's largest rivers, ranking in the top 10 in discharge, length, and watershed area (Czaya 1981). For the past several decades, the Mississippi River also has been one of the world's largest rivers in terms of nitrate load exported to coastal oceans (Goolsby and Battaglin 2001; Dai et al. 2011). Along with silica and phosphorous that are also delivered by the Mississippi River (Sylvan et al. 2011), nitrate is recognized as a potent fertilizer for phytoplankton in coastal marine waters (Turner et al. 2006; Scavia and Donnelly 2007). Later decomposition of phytoplankton in stratified bottom waters can lead to hypoxia, or low dissolved oxygen concentrations in bottom waters of $<2 \mathrm{mg} \mathrm{l}^{-1}$ or $<64 \mathrm{mmol} \mathrm{m}^{-3}$. Historical trends in nitrate concentrations for the lower Mississippi River discharge to the Gulf of 
Mexico have been reconstructed by Goolsby and Battaglin (2001). Nitrate concentrations were low (about $0.1 \mathrm{mg} \mathrm{l}^{-1}$ or $7 \mathrm{mmol} \mathrm{m}{ }^{-3}$ ) before European settlement of North America, then increased about 6-fold with land clearing by 1900 . Nitrate concentrations rose further to $1.5 \mathrm{mg}^{-1}$ or $110 \mathrm{mmol} \mathrm{m}^{-3}$ by the late 1970 s due to extensive fertilizer use in the midwest. Overall, there has been a 15 - to 20 -fold increase in river nitrate concentrations versus background (Goolsby and Battaglin 2001; Rabalais et al. 2007). Historical reconstruction of hypoxia using indicator foraminifera in cores taken from the Louisiana shelf shows that hypoxia may have been present at times over the last 1,000 years (Osterman et al. 2008; 2009). Widespread recurrent hypoxia has been detected near areas of river inputs on the Louisiana continental shelf starting in the mid-1970s (Rabalais et al. 2002; Justić et al. 2002). Regular summertime cruises since 1985 document the size and extensive distribution of hypoxic bottom waters across the Louisiana shelf, with the summer hypoxic area averaging 13,500 $\mathrm{km}^{2}$ for 19852009 (Rabalais et al. 2010). For comparison, the land area of the state of Connecticut, USA is about $12,500 \mathrm{~km}^{2}$, and restoration goals are to reduce the average hypoxia area to $<5,000 \mathrm{~km}^{2}$ (Dale et al. 2009).

Although river nutrient loads are the factors that have changed most during the last decades and, thus, seem primarily responsible for recently intensified hypoxia (Turner et al. 2006, 2008, 2011), other factors also have been shown to be important (reviewed in Rabalais et al. 2007; Bianchi et al. 2010; Rabalais et al. 2014). For example, freshwater itself introduced by the Mississippi River promotes strong stratification that isolates bottom waters so that oxygen deficits develop in the absence of mixing and reaeration by oxygen in the atmosphere. Coastal ocean circulation dynamics are also very important controls of hypoxia formation and dissipation (Wang and Justić 2009), and generally, physics plays an equally strong role with biology in forcing hypoxia (Hetland and DiMarco 2008). New aspects of biological controls of hypoxia are emerging as well. Recently benthic and mid-water photosynthesis has been reevaluated for shelf waters and can be important in slowing the rate of oxygen decline in bottom waters (Lehrter et al. 2009; Grippo et al. 2010; Baustian et al. 2011). Other studies have hypothesized that the addition of particulate soil carbon from marsh and riverine sources (Dagg et al. 2007) may be necessary to balance model carbon budgets related to hypoxia formation (Breed et al. 2004; Green et al. 2006). One field study showed that algal sedimentation in this area can be low under some high productivity summer conditions (Redalje et al. 1994), leading to a possible inference of strong off-shelf export of the river-fueled algal production. In this case, extra carbon is required to fuel the observed extensive hypoxia, and carbon export or outwelling from local estuaries has been hypothesized as possibly important in this regard (Dagg et al. 2007; Bianchi et al. 2011). However, two recent modeling studies reporting long-term measurements for one important deltaic estuary of the region, Barataria Bay, do not support the carbon outwelling hypothesis (Das et al. 2010, 2011). Because confidence generally is lower when models do not agree in their major outcomes (Scavia et al. 2004; Justić et al. 2007), we undertook repeated field studies during annual summer shelfwide cruises from 2006 to 2010 to test how riversupported carbon productivity is coupled to hypoxia. The goal was to identify and map surface waters where production $(P)$ exceeded respiration $(R)$ and net autotrophy prevailed $(P / R>$ $1)$, with net autotrophic surface waters needed to supply carbon and fuel hypoxia in bottom waters.

This study reports two sets of measurements not previously coupled in studies of this shelf ecosystem: carbon measurements of particulate organic carbon (POC), dissolved inorganic carbon (DIC), and dissolved organic carbon (DOC) dynamics, and oxygen measurements of net ecosystem metabolism (NEM). The carbon field measurements show formation of particulate materials in low salinity, river-influenced phytoplankton blooms, with increasing $\mathrm{pH}$ and decreasing DIC concentrations accompanying these blooms. The DIC measurements allowed budget calculations of carbon removal in the blooms, for comparison to river nutrient loading. To further characterize the surface productivity dynamics, NEM oxygen measurements were made in 24-h shipboard incubations. In these incubations, light bottles were exposed to the ambient light/dark cycle, and dark respiration $(R)$ oxygen measurements were conducted in parallel. These incubation measurements identified places where surface waters were net autotrophic. The NEM samples were collected from the surface mixed layer to investigate spatial patterns of net autotrophy because shelf waters below the surface mixed layer are net heterotrophic (Lehrter et al. 2009, 2012).

Most previous studies have emphasized an upstreamdownstream or east-to-west view of productivity and hypoxia dynamics for this shelf ecosystem (e.g., Green et al. 2006; Liu et al. 2010) and usually $<10 \%$ of stations are located in shallow nearshore waters $<15 \mathrm{~m}$ deep (e.g., Lehrter et al. 2009, this study). Here we raise the possibility that these nearshore areas are much more important than previously thought, in agreement with some previous measurements (Chen et al. 2000) and observations that the role of wellmixed nearshore waters should not be ignored due to their "high productivity along the inshore edge of the hypoxic zone" (Boesch 2003, p. 204). The overall hypothesis of this work was that a band of nearshore waters was responsible for most net productivity in this shelf ecosystem and that POC produced in these waters in the spring and summer moved seaward along the bottom to help fuel mid-shelf hypoxia. These ideas were investigated in five successive summer shelfwide cruises, 2006-2010, in one spring cruise in 2007, and in seasonal spring-summer studies along a mid-shelf 
transect in the flood year of highest river flows, 2008. To complement these field efforts, a preliminary biogeochemical budget is presented linking riverine nitrogen loading with carbon productivity important for summer hypoxia. This budget is largely synthesized from existing literature, with an exception that estimates of DOC and POC carbon loading from the Mississippi River and adjacent estuaries are updated from Das et al. (2010, 2011). These updates are made with new data on carbon lability from 28-day decomposition experiments reported here.

\section{Study Area and River Inputs}

The Louisiana shelf ecosystem was studied during cruises along multiple transect lines in each of the five summers (Fig. 1). Samples were collected as part of annual 5-8-day shelfwide cruises in late July (exact dates were 22-26 July 2006, 21-28 July 2007, 21-28 July 2008, 20-24 July 2009, and 25-31 July 2010). Both the Atchafalaya River and the mainstem Mississippi River influence the central shelf, carrying about $70-80 \%$ of the total river flow (Dinnel and Wiseman 1986; Roberts 1998; Etter et al. 2004; Hetland and DiMarco 2008; Lehrter et al. 2013), with largest outflows at Southwest (SW) Pass (Fig. 1). River flows and forcings were typically strong for several spring and early summer months preceding these mid-summer July cruises, and mid-shelf hypoxia development has been correlated best with river inflows lagged by 1-3 months (Justić et al. 1996). River flows also have been estimated to arrive in mid-shelf surface waters with a 15-day lag (Wiseman et al. 1997), and phytoplankton blooms are detectable with remote sensing with 4-5 week lags (Walker and Rabalais 2006), so that overall shelfwide patterns observed in July likely reflected the previous 28 weeks of river dynamics. These estimates are in line with those of Sylvan and Ammermann (2013) who recently concluded that it takes 1 month for river total nitrogen (TN) and total phosphorous (TP) to be incorporated by this shelf ecosystem during spring and summer conditions.

The average river flows for July compiled by the USACE (http://www.mvn.usace.army.mil/Missions/Engineering/ StageandHydrologicData.aspx) varied by a factor of 2.6 across the years, with the lowest flow in $2006\left(9,288 \mathrm{~m}^{3} \mathrm{~s}^{-1}\right)$ and moderate-to-high flows in the remaining years, 2007 $\left(19,474 \mathrm{~m}^{3} \mathrm{~s}^{-1}\right), 2008\left(28,378 \mathrm{~m}^{3} \mathrm{~s}^{-1}\right), 2009\left(18,913 \mathrm{~m}^{3} \mathrm{~s}^{-}\right.$ $\left.{ }^{1}\right)$, and $2010\left(24,184 \mathrm{~m}^{3} \mathrm{~s}^{-1}\right)$. These July flows were somewhat reduced compared to highest spring flows in MarchMay, averaging 51-94\% of spring flows in 2006-2010, but were still substantial when compared to a long-term annual average river flow of $20,565 \mathrm{~m}^{3} \mathrm{~s}^{-1}$ (as compiled for the Mississippi River plus its Atchafalaya River distributary for 50 years, January 1963 to December 2012, using data from the website listed above). The July flows ranged from 47 to $144 \%$ of this annual mean flow, with July flows in 2 years of particular interest in this manuscript, 2008 and 2009, respectively, averaging 144 and $96 \%$ of this annual average flow.

River inputs of freshwater were thus near-average during the shelfwide cruises, and most parameters measured had strong salinity-related patterns that proved surprisingly robust and repeatable across the study years. Those patterns are reported here for $\mathrm{pH}$ and POC in all 5 years (2006-2010). More detailed studies of carbon dynamics were undertaken in some years, particularly in 2008 which was a high-water flood year with average spring discharges reaching $58,900 \mathrm{~m}^{3} \mathrm{~s}^{-1}$ in
Fig. 1 Study area and surface salinity distributions in late July for two shelfwide cruises: a 2008 (flood year) and b 2009 (moderate flow year). Symbols indicate salinity zonation: diamonds $=<20$, squares $=20-25$, triangles $=25-30$, times symbols $=30-36$. Letters indicate station transects studied during annual shelfwide cruises (Rabalais et al. 2002). Brackets indicate two groups of stations: transect lines $\mathrm{A}, \mathrm{B}$, and $\mathrm{C}$ in the east and transect lines $\mathrm{H}, \mathrm{I}, \mathrm{J}$, and $\mathrm{K}$ in the west, with data from stations in these two transect groups used to construct Fig. 8. Dashed polygons indicate the average extent of summer hypoxic waters (Rabalais et al. 2002)
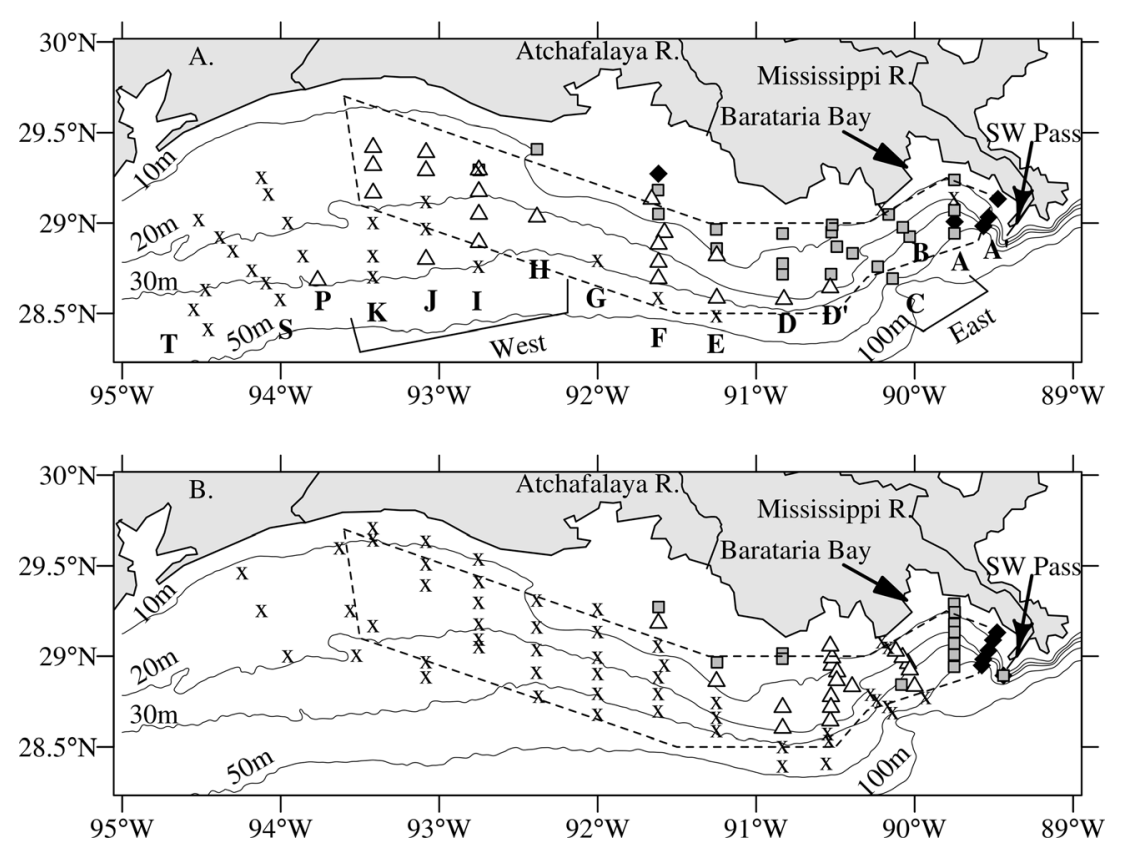
April. Monthly samples were collected along transect C (Fig. 1) during March-August 2008 to help assess whether shelfwide trends observed during the late July cruises also applied over the longer spring-summer hypoxia season. For comparison with the offshore samples, some water samples from the Mississippi River and from a nearby estuary, Barataria Bay (Fig. 1), also were analyzed. Weekly and biweekly samples were also taken at Baton Rouge, $397 \mathrm{~km}$ upstream of the river mouth at Southwest Pass. These samples were used to characterize nutrients and carbon in the Mississippi River, establishing end-member nitrate and carbon values that can vary seasonally in rivers (Cai et al. 2008; Guo et al. 2012). These measured endmember values are summarized in the Appendix.

\section{Methods}

Most samples were collected with Niskin bottles on shelfwide cruises, and some surface samples were collected with plastic buckets. Surface water $\mathrm{pH}$ was measured using temperaturecompensated probes from Hydrolab and YSI. Probes were calibrated before each cruise with two NBS buffers, $\mathrm{pH}=7.0$ and 10.0. Manufacturer specifications were \pm 0.01 resolution for the probes, and typical reproducibility of field measurements was $\pm 0.02 \mathrm{pH}$ units. Temperature, salinity and oxygen profiles were measured with calibrated Sea-Bird instruments mounted on a Niskin rosette sampler.

POC and particulate organic nitrogen (PON) samples were collected onto precombusted $\left(450{ }^{\circ} \mathrm{C}, 4 \mathrm{~h}\right) \mathrm{GF} / \mathrm{F}$ glass fiber filters from water samples of 200-2,000 ml. Filtration was conducted onboard the ship within 30 min of collection, with approximately $1 \mathrm{ml}$ of deionized water added at the end of filtration to rinse out salt. Filters were frozen on the ship, later thawed in the laboratory, then $0.5 \mathrm{ml}$ of $0.1 \mathrm{~N} \mathrm{HCl}$ was added with a pipette to decompose carbonates, and filters were dried without rinsing at $60{ }^{\circ} \mathrm{C}$. Filters were analyzed for POC and PON concentrations with a coupled elemental analyzer-isotope ratio mass spectrometer system (Carman and Fry 2002). Data were blank-corrected and the practical limits of detection above blanks were $2 \mathrm{mmol} \mathrm{POC}^{-3}$ and $0.4 \mathrm{mmol} \mathrm{PON} \mathrm{m}^{-3}$.

In some cases, GF/F filtrates were stored refrigerated for $7-$ 14 days before laboratory analysis of DOC. GF/F filters were used following their earlier use in studies of DOC in this area by Pakulski et al. (2000), but it should be noted that these filters allow some smaller sized bacteria to pass into the filtrates (Coffin et al. 1989). Thus, the reported DOC values from GF/F filtration may be somewhat elevated versus DOC values from 0.2 or $0.45 \mu \mathrm{m}$ filtered water where nearly all bacteria have been removed (e.g., Benner and Opsahl 2001). DOC concentrations were analyzed after automated acidification and DIC removal using a Shimadzu total carbon analyzer (APHA et al. 2005). DOC data were standardized using a $20-\mathrm{mg}^{-1}{ }^{-1}\left(1,667 \mathrm{mmol} \mathrm{m}^{-3}\right.$ DOC) organic carbon addition of potassium hydrogen phthalate to deionized water, with measurements of standard and deionized water across 150 multiple runs yielding averages + SEM of $1,708 \pm 7$ and $75 \pm 5 \mathrm{mmol} \mathrm{m}^{-3} \mathrm{DOC}$, respectively.

Samples for total $\mathrm{CO}_{2}$ (or DIC) concentrations and oxygen concentrations were analyzed as detailed in Wissel et al. (2008). Procedures involved adding a helium headspace to unfiltered samples in $165 \mathrm{ml}$ Wheaton vials, shaking bottles for $>24 \mathrm{~h}$ to promote gas equilibration, and then injecting headspace samples into a coupled gas chromatograph-isotope ratio mass spectrometer system (Wissel et al. 2008). DIC samples were collected in all years, but data are presented here only for 2 years (2008 and 2009) where sampling of river end-members was relatively complete. Weekly and biweekly surface water samples were collected from the Mississippi River at Baton Rouge to serve as riverine end-members in mixing models. Nitrate+ nitrite was measured in these river samples using a Lachat autoanalyzer using the standard cadmium reduction and colorimetric nitrite assay method (APHA 1989).

NEM was measured using 24-h incubations of unfiltered water. Changes in final and initial dissolved oxygen were measured to give NEM (=final light bottle oxygen-initial bottle oxygen), $R$ (=initial bottle oxygen-final dark bottle oxygen), and gross production $(P)$ where $P$ is the sum of NEM and $R$. For the light bottle incubations, $165 \mathrm{ml}$ Wheaton serum bottles were placed in flowing seawater on the deck, exposed to the ambient light/dark cycle, and shaded by a single layer of neutral density screening that reduced any surface light by $39 \%$ (Lehrter et al. 2009). For the dark bottle incubations, $R$ was measured for surface samples in filled $165 \mathrm{ml}$ Wheaton serum bottles held $24 \mathrm{~h}$ in dark containers on deck and maintained at sea surface temperatures.

Dark incubations in the laboratory also were used to determine potential lability of carbon loads entering the offshore system from river and estuarine sources. For these incubations, water samples were collected at weekly to monthly intervals during 2009 and 2010. Samples of $150 \mathrm{ml}$ were placed in $165 \mathrm{ml}$ Wheaton serum bottles, leaving $15 \mathrm{ml}$ of air as an oxygen reserve that held $>4 \times$ more oxygen than that required by respiration during the incubations. The bottles were sealed with blue stoppers (Wissel et al. 2008) with needle vents to air; these vents also allowed some oxygen resupply from the atmosphere. Incubation bottles were placed on a laboratory shaker table and agitated gently for 28 days at $23{ }^{\circ} \mathrm{C}$ in the dark. Initial and final samples of POC and DOC were analyzed to determine the fraction that was potentially labile under field conditions during the 4-week dark laboratory incubations. A 1-month time scale was chosen for incubations because initial observations showed that plankton decomposed completely within 1-2 weeks, older observations show that most labile DOC is consumed within 4 weeks (Ogura 1972), and a period of 1 month is a typical time for river-influenced biological dynamics in this shelf ecosystem (Sylvan and Ammermann 2013). 


\section{Results}

Carbon Dynamics Across the Salinity Gradient

Shelfwide cruises consistently showed that salinity increased in surface waters to the south and the west of Mississippi and Atchafalaya River freshwater inputs (Fig. 1). Mixing gradients were steep in this offshore region, and salinities $<20$ were confined narrowly to areas near river mouths (Fig. 1). Midrange salinities of 20-25 were common downstream of Southwest Pass in the flood year 2008 (top panel of Fig. 1), but much less common in moderate and low flow years (e.g., 2009, bottom panel of Fig. 1). In all years, most stations had salinities $>25$ (Fig. 1).

On all cruises, $\mathrm{pH}$ showed rapid increases with salinity from relatively low values near 7.7 in the Mississippi River upstream of Southwest Pass, to maximum values near 9 at salinities near 15 (Fig. 2a). This increase in $\mathrm{pH}$ coincided with areas of POC formation (Fig. 2b) and is expected in areas influenced by plankton blooms, because of the utilization of inorganic carbon (the weak acid $\mathrm{CO}_{2}$ ) during algal growth (Guo et al. 2012). C/N ratios for the samples of Fig. 2b averaged $7.16 \pm 0.15$ (mean+SEM, $n=429)$.

The salinity-related $\mathrm{pH}$ and POC dynamics were closely tied to carbon cycling, and the net carbon withdrawal from surface waters was investigated via DIC measurements in 2008 and 2009. A large carbon deficit was evident from the DIC measurements, with the deficit completely developed by a salinity of 17.5 (Fig. 3). Qualitatively, this DIC deficit
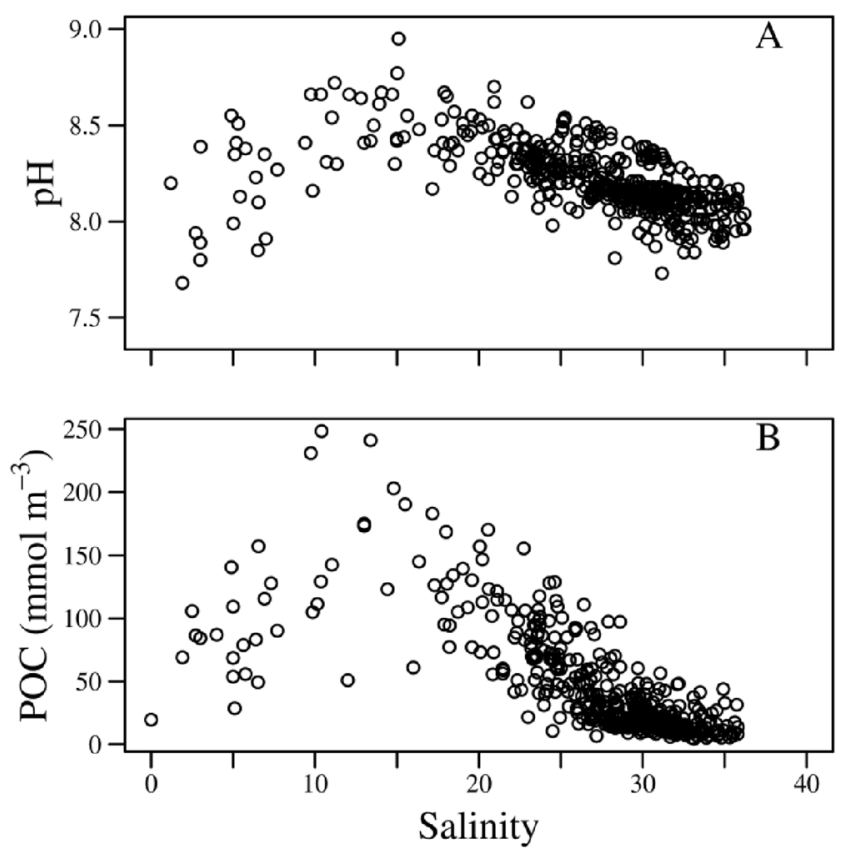

Fig. 2 a pH versus salinity for 5 years of shelfwide surface data, 20062010. pH increases at low salinity due to phytoplankton uptake of DIC, then declines due to linear mixing with higher salinity waters. b POC surface concentrations from 5 years of shelfwide cruises, 2006-2010 reached maximum development in the same 10-20 psu salinity range (Fig. 3) that the maximum $\mathrm{pH}$ and maximum $\mathrm{POC}$ were observed (Fig. 2), so that the DIC deficit appeared linked to carbon drawdown by phytoplankton.

This DIC deficit was also assessed in more quantitative terms using two linear mixing scenarios, one involving conservative mixing and the other scenario involving complete use of nitrate + nitrite by phytoplankton (top 2 lines in Fig. 3). Details about the end-members used in these scenarios are given in the Appendix. The conservative DIC mixing line (top line, Fig. 3a) connected July end-member values for the Mississippi River and those for high salinity offshore waters. DIC concentrations fell mostly below this mixing line, indicating net DIC removal. A second mixing line was constructed for a theoretical scenario in which dissolved inorganic nitrate + nitrite (DIN) was completely removed by phytoplankton growing at the mouth of the river at 0 salinity, with the resulting phytoplankton-induced DIC deficit then diluted across the salinity gradient. This theoretical scenario that moves forward from a freshwater end-member across the salinity gradient is related to calculations made with the apparent zero end-member (AZE) method critically reviewed by Regnier et al. (1998), where trends for high salinity data are back-extrapolated to 0 salinity and conditions of complete DIN use. The back extrapolations of the AZE method and the forward calculations based on complete DIN use gave very similar results for the July 2008 and 2009 cruises (see Appendix), and the forward calculations are shown in the middle line in Fig. 3. Observed DIC data for both 2008 and 2009 fell along this middle line at salinities of 17.5 and above, consistent with complete DIN use. Thus, net autotrophy at low salinities was indicated by complete development of a DIC deficit by salinity of 17.5, a deficit that then diluted as expected for recycling systems without any further net autotrophy.

We examined several other data sets for similarly strong $(>50 \%)$ net autotrophic removal of DIC at low salinities. The calculation of net autotrophic removal can be illustrated using the upper two lines in Fig. 3, with points close to the middle line indicating greater DIC removal. The two upper lines (Fig. 3) provide end-member values that vary with salinity, with points along the top line giving the no removal $(0 \%$ net autotrophy) end-members and points along the middle line giving the complete removal (100\% net autotrophy) endmembers. The data sets assessed for net autotrophic DIC removal included several shelfwide and monthly observations as follows: There were five shelfwide cruises conducted by EPA scientists (Lehrter et al. 2013, EPA unpublished data) in 2006 and 2007 at low and moderate river flows (13-17 April 2006, 14,528 $\mathrm{m}^{3} \mathrm{~s}^{-1}$; 6-11 June 2006, 13,631 $\mathrm{m}^{3} \mathrm{~s}^{-1} ; 6-11$ Sept 2006, 6,792 $\mathrm{m}^{3} \mathrm{~s}^{-1} ; 2-7$ May 2007, 26,961 $\mathrm{m}^{3} \mathrm{~s}^{-1} ; 19$ 23 August 2007, 10,644 $\mathrm{m}^{3} \mathrm{~s}^{-1}$ ). Autotrophic DIC removal was complete (i.e., consistent with complete DIN use and falling on a straight dilution line with high salinity offshore 


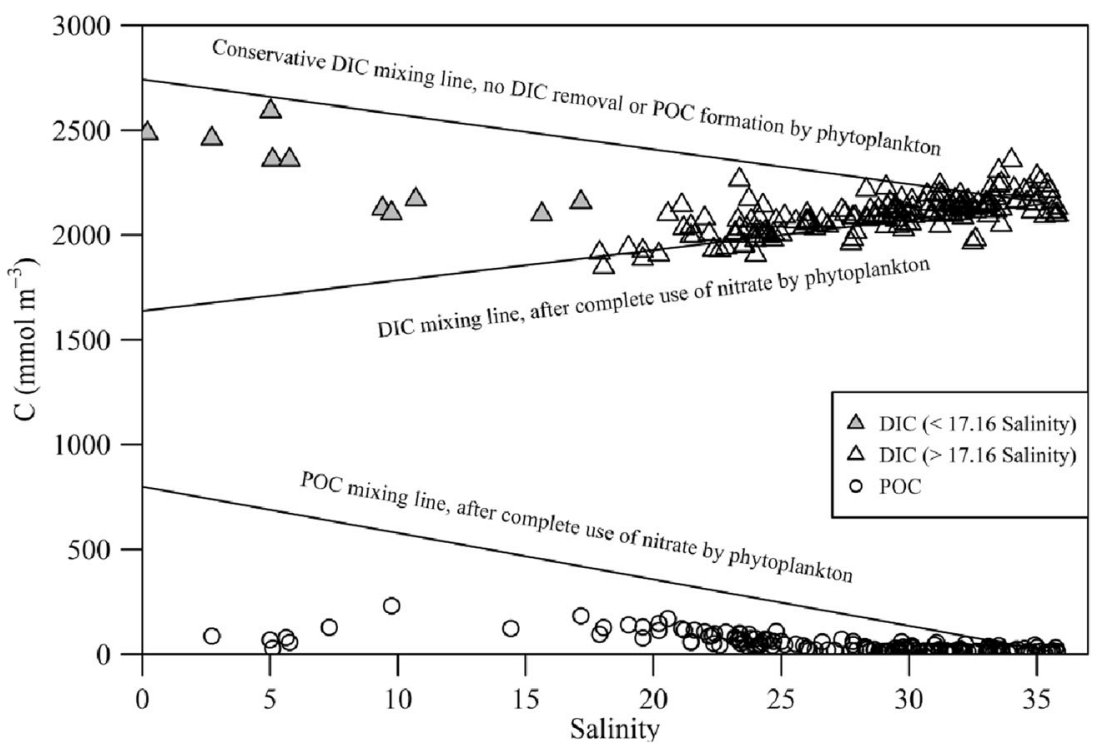

Fig. 3 DIC dynamics versus salinity for two pooled years of surface shelfwide data, 2008 and 2009. Data gave similar trends for each year and have been pooled for simplicity of presentation. A large DIC deficit develops at higher salinities $(>17.16$, open triangles $)$ relative to the straight line conservative mixing expectation (top line) between river and marine source waters. Middle line shows theoretical DIC deficit

water, represented in Fig. 3 by the middle line) by salinities of 20 to 26 in all of these shelfwide surveys except the May 2007 cruise. During the May 2007 cruise at a time of higher river flows, DIC drawdown was incomplete (or approximately $50 \%$ complete) at salinities of 20-30 and autotrophic potential extended further offshore into mid-shelf waters. We also examined monthly data collected across transect $\mathrm{C}$ during the high flood year of 2008, where spring and summer flows of the Mississippi River consistently averaged $>20,000 \mathrm{~m}^{3} \mathrm{~s}^{-1}$. Water collected along the $\mathrm{C}$ transect during April and May at times of highest river flows (averages near 50,000 $\mathrm{m}^{3} \mathrm{~s}^{-1}$ ) showed low salinities (mostly less than 21) and incomplete (or approximately 50-75\% complete) DIC removal. But in later months in 2008 when flows were still high or moderate (June and August flows at the time of sampling were about 30,000 and $20,000 \mathrm{~m}^{3} \mathrm{~s}^{-1}$, respectively), DIC removal was complete at relatively low salinities of 15-22. Overall, the shelfwide and monthly data from times other than July generally agreed with the pattern of near-complete DIC drawdown occurring at low salinities and nearshore, with some exceptions during very high flow spring conditions $\left(>25,000 \mathrm{~m}^{-3} \mathrm{~s}^{-1}\right)$ when flow and winds likely combined to dilute river water out over the shelf faster than net autotrophic $\mathrm{C}$ uptake.

The POC dynamics also were of interest in relation to DIC, with POC expected to accumulate as DIC was consumed. Close correspondence between DIC consumption and POC formation is represented by the bottom line of Fig. 3. This bottom line represents a theoretical mixing scenario for POC considering phytoplankton grow using all nitrate + nitrite to form POC at the river mouth, then dilute across the salinity dynamics expected for complete net autotrophic phytoplankton use of DIN at 0 salinity, followed by dilution of this DIC deficit at higher salinities. Bottom line shows POC formation expected for complete DIN use at 0 salinity, followed by dilution, with lower measured POC concentrations indicating POC removal even as POC is forming

gradient. End-member data for this POC mixing are given in the Appendix. The POC concentrations were generally much below the expected theoretical mixing line (Fig. 3) and indicate that POC formed from DIC simultaneously must have been lost or removed from surface waters, presumably via grazing or sedimentation. The fraction removed for the combined 2008 and 2009 data shown in Fig. 3 could be calculated as the deviation-from-complete-reaction bottom mixing line in Fig. 3 and was $68 \%$ at salinities of 15-20 and rose to 80 $85 \%$ at salinities $>20$. These removal percentages also were calculated for the combined 2006-2010 shelfwide POC data (Fig. 2), with the percentage removed given as mean+SEM (n) as $66 \pm 8 \%(10)$ at salinities of $10-15,68 \pm 2 \%(17)$ at salinities of 15-20, 71+1\% (78) at salinities of $20-25,79 \pm$ $1 \%(147)$ at salinities of 25 to 30 , and $80 \pm 1 \%$ (131) at salinities of 30-34. Surface POC concentrations at salinities $>34$ were near background (about 5-15 $\mathrm{mmol}$ POC $\mathrm{m}^{-3}$ ) and did not allow accurate estimates of POC removal. Overall, the coupled view of $\mathrm{DIC}$, nitrate+ nitrite, and POC dynamics (Fig. 3) indicated rapid phytoplankton growth and DIC removal to values expected of complete DIN use in low salinity $(<20)$ surface waters, along with both POC formation and simultaneous POC loss occurring in these waters. Thus, carbon transfers were substantial at low salinities, first out of surface water DIC pools into POC pools then out of surface water POC pools to grazers and sedimentation. In situ respiration of surface POC would have replenished DIC pools and elevated DIC concentrations so that higher salinity points would fall near the upper line of Fig. 3, an effect not observed. 


\section{Oxygen Dynamics and Metabolism of Surface Waters}

We also used oxygen concentration measurements to investigate the bloom dynamics indicated by the July carbon results of Figs. 2 and 3. Shipboard oxygen measurements of metabolic rates in surface waters generally showed highest NEM and $R$ nearshore and close to river mouths (Fig. $4 \mathrm{a}-\mathrm{d}$ ), with higher-than-average $R$ also present in some offshore samples on the eastern shelf (Fig. $4 \mathrm{~b}, \mathrm{~d}$ ). Low $R$ was observed to the west and offshore in both 2008 and 2009 (Fig. 4b, d), and NEM was negative for most of these stations, indicating net heterotrophy in these surface samples (Fig. 4a, c). The samples with the highest NEM occurred at low salinities in the 510 range at stations $\mathrm{A}^{\prime} 1-\mathrm{A}^{\prime} 4$ near Southwest Pass in 2008. Ambient oxygen saturation values for these samples collected in the early afternoon were also high at 130-195\%. Thus, the strong net autotrophic signals in NEM incubations were also accompanied by strong ambient productivity signals measured as oxygen supersaturation in low salinity waters.

Overall, most of the shelf metabolic patterns could be related to depth (Fig. 5) with the highest shelfwide rates of NEM in waters $<10 \mathrm{~m}$ in both 2008 and 2009. There was one important exception to the depth-related patterns in 2008, when higher river flow led to high net autotrophy in surface waters near SW Pass (Fig. 5a). This exception occurs because the river plume spreads over deeper waters that are close to shore in this region. In the moderate flow year of 2009, samples from the same Southwest Pass area followed the depth trend noted for the rest of the shelf (Fig. 5a), and samples collected across spring and early summer months in the flood year 2008 offshore of the Atchafalaya River also showed the rapid NEM decline with depth (Fig. 5b). Overall, these patterns indicated that depth-related trends for NEM were the norm for this shelf, with high flows near SW Pass in 2008 providing an important exception that pushed net autotrophic waters further offshore.

The metabolic $R, P$, and NEM patterns were also summarized by weighting data for surface mixed layer depths and for areas associated with increasing distance offshore. Mixed layer depths (MLD) for surface waters were estimated following Guo et al. (2012) from salinity $(S)$ as $\mathrm{MLD}=S \times 4 / 25$ for salinities $<25$ and $\mathrm{MLD}=S-21$ for salinities $>25$. Areal weightings were obtained by estimating shelf areas at $5 \mathrm{~m}$ depth intervals and normalizing the station density to reflect these relative areas. This weighted analysis shows where most metabolism is occurring in surface waters of the shelf, with areas inshore of $15 \mathrm{~m}$ providing most of the positive NEM during the 2008 and 2009 shelfwide cruises while $R$ was more broadly distributed across the shelf (Fig. 6). Gross $P$ and NEM were focused more nearshore during the moderate flow year of 2009 , so that almost $100 \%$ of net autotrophy occurred in the nearshore area $<15 \mathrm{~m}$ (Fig. 6c). In contrast, higher river flows near SW Pass in 2008 led to productive offshore waters near SW Pass, so that only $65 \%$ of positive NEM occurred inshore of $15 \mathrm{~m}$ and $35 \%$ in offshore waters $>45 \mathrm{~m}$ deep near SW Pass. If the 2 years of moderate and high flows are averaged for a long-term summer mean, about $80 \%$ of the net autotrophy for the system occurred in nearshore waters, with $20 \%$ in deeper waters near SW Pass. Both 2008 and 2009 had characteristic declines in NEM offshore of $15 \mathrm{~m}$ (Fig. 6c) that indicate net heterotrophy in surface waters for most of the offshore shelf, with the exception that higher flows in 2008 led to net autotrophy in surface waters for stations in deeper water near SW Pass (Fig. 6c, square points for depths $>35 \mathrm{~m}$ ).

\section{POC in Vertical Profiles and Bottom Waters}

Carbon and oxygen measures of productivity both indicated that near-river (Figs. 1 and 3) and shallow nearshore areas were the areas where the majority (65-95\%, Fig. 6c) of net productivity occurred, with these areas located just inshore of mid-shelf hypoxic zones. Local cross-shelf carbon transport seemed possible from nearshore to mid-shelf areas, feeding hypoxic oxygen demand on a continuing basis. One likely mechanism of cross-shelf feeding would be POC transport in bottom waters, with waves and winds combining to slowly move particles seaward into calmer mid-shelf hypoxic waters. We collected POC profiles at many stations, and detailed profiles were possible in April 2007 with calm conditions and a submersible pumping system that allowed sample collection at submeter resolution. These POC profiles (Fig. 7) showed two typical features, i.e., lower POC concentrations in deeper offshore waters and increased POC concentrations in near-bottom waters (Fig. 7). In subsequent cruises, we focused more on near-bottom (within $2 \mathrm{~m}$ of bottom) measurements of POC and related variables. In particular, POC and DIC measurements were made in bottom waters during the 2008 shelfwide cruise, with observations made at stations on the eastern shelf (Fig. 8a, c) and on the western shelf (Fig. 8b, d). In both cases, the cooler, higher salinity waters of the mid-shelf hypoxic zone were well-separated from the warmer, less saline nearshore waters along an interface at 10-15 m bottom depth offshore (Fig. 8), and low oxygen levels approaching $0 \mathrm{mmol} \mathrm{m}{ }^{-3}$ were observed at about $20 \mathrm{~m}$ bottom depth offshore. Highest DIC levels accompanied these oxygen minima, with the calculated DIC excess representing respired carbon. DIC end-members used in these calculations were the same as those used in the conservative mixing calculations of Fig. 3 and presented in the Appendix. The nearshore areas $<15 \mathrm{~m}$ deep showed negative DIC excess (a DIC drawdown) characteristic of net autotrophy in shallow productive waters. These nearshore bottom waters also showed higher POC concentrations, with POC values declining offshore (Fig. 8c, d) as expected for export from the nearshore productive zone via, e.g., sediment resuspension and transport along the bottom. These types of gradient 

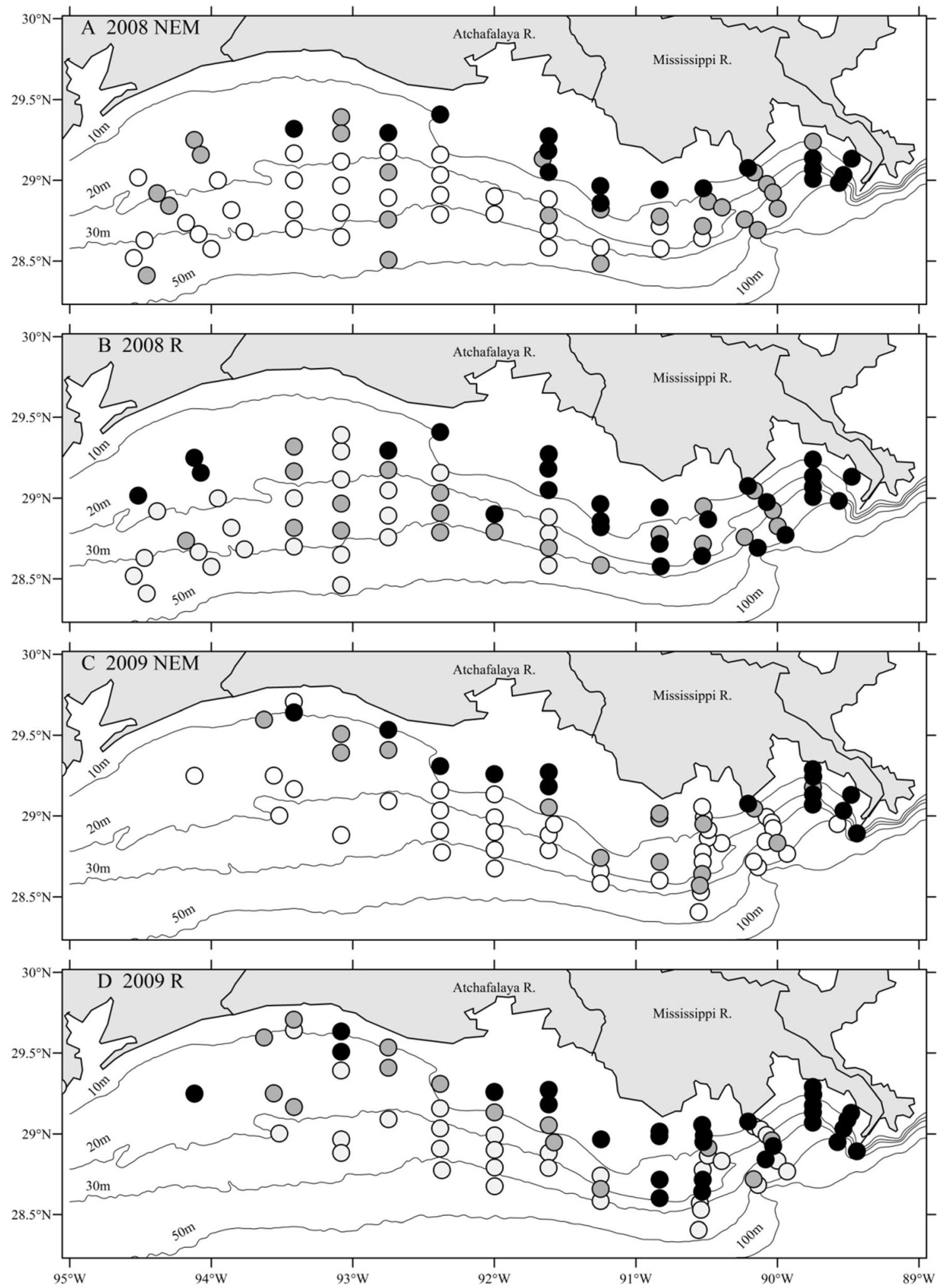

Fig. 4 Net ecosystem metabolism, $\operatorname{NEM}(\mathbf{a}, \mathbf{c})$, and respiration, $R(\mathbf{b}, \mathbf{d})$, measured in shipboard incubations, 2008 (a, b) and 2009 (c, d) July shelfwide cruises. Data was binned into three classes for NEM (expressed in mmol dissolved oxygen $\mathrm{m}^{-3}$ day $^{-1}$ as $<0$ (open circles), 0-23 (gray circles), and $>23$ (444 maximum; black circles) where average NEM over the 2 years was $23 \mathrm{mmol} \mathrm{m}^{-3}$ day $^{-1}$. Data for $R$ (expressed in mmol $\mathrm{m}^{-3}$ day $^{-1}$ ) was similarly binned into three groups: $<8$ (light gray circles), 8-16 (medium gray circles), and >16 (152 maximum; black circles) where average $R$ over the 2 years was $16 \mathrm{mmol} \mathrm{m}^{-3}$ day $^{-1}$ 


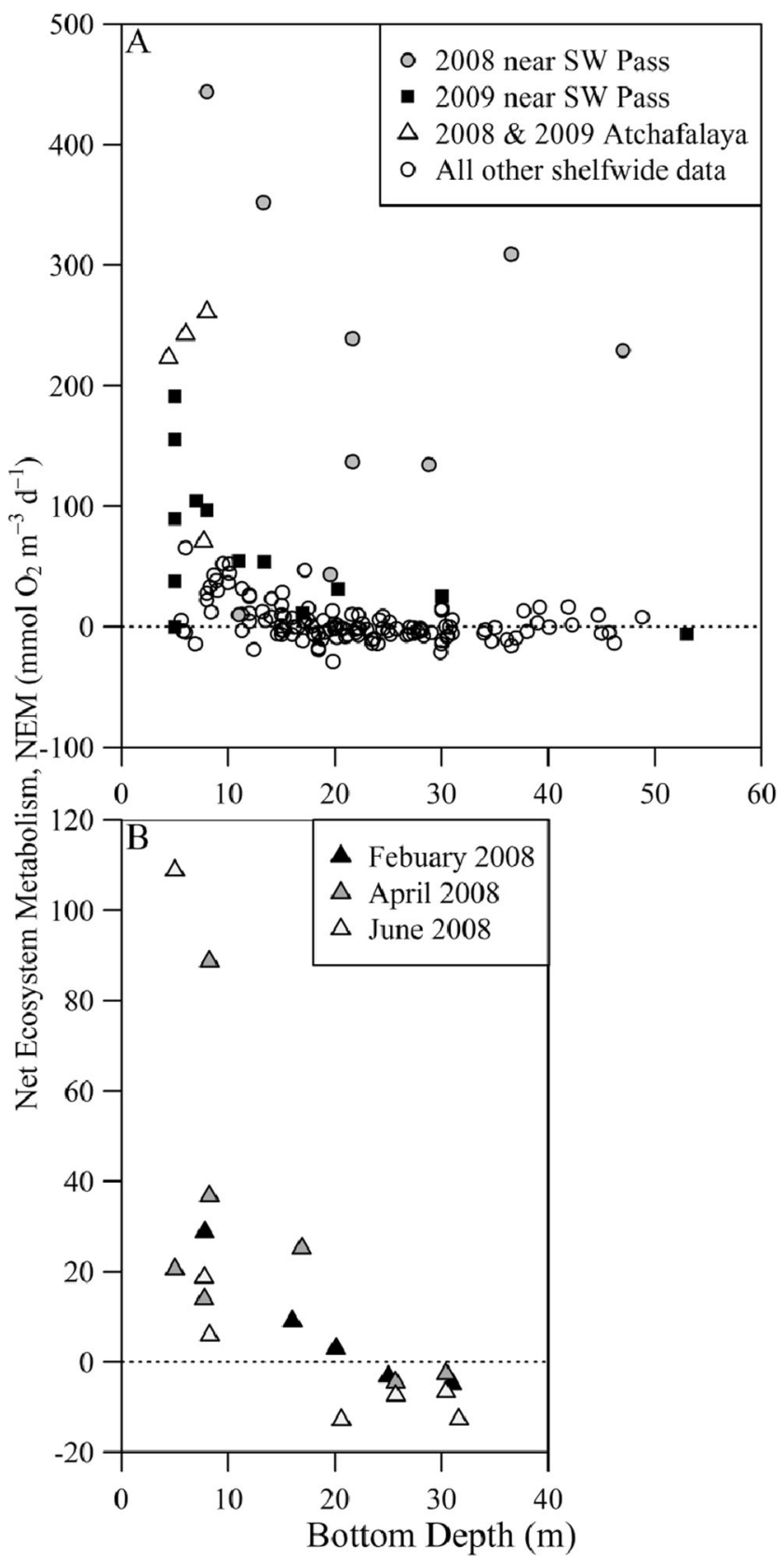

Fig. 5 Net ecosystem metabolism (NEM) versus depth offshore for 2008 and 2009 shelfwide data (a) and for monthly data in spring and summer of 2008 for the F transect near the mouth of the Atchafalaya River (b)

declines in POC with distance offshore were generally observed for the 2008 samples of the shelfwide survey (Fig. 8) and also for samples collected in spring and summer months in 2008 along the $\mathrm{C}$ transect of the central shelf (Fig. 9). Only $6 \%$ of all data (or $15 \%$ of the shelfwide-only data, Fig. 9) showed higher POC concentrations in the mid-shelf region that departed from this cross-shelf gradient in carbon concentrations (see black and gray triangles near 20 salinity in Fig. 9). Overall, the regular crossshelf gradients in POC were consistent with POC movement from nearshore to offshore waters, a movement of carbon and

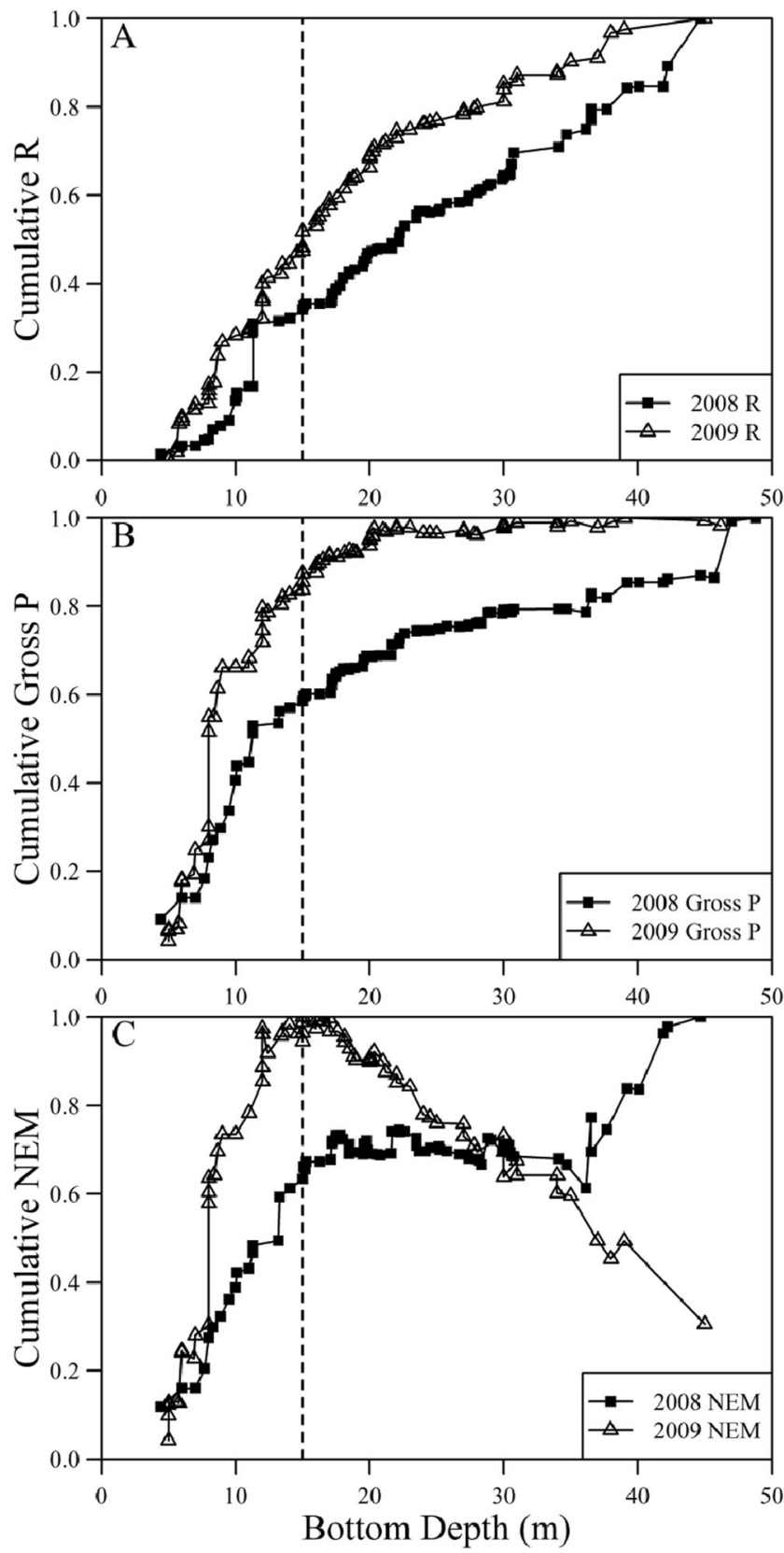

Fig. 6 Cumulative $R$ (a), gross $P(\mathbf{b})$, and NEM (c) metabolic data versus depth offshore for 2008 and 2009. Measured metabolic data were weighted for mixed layer depth and shelf area then accumulated from shallow to deep across the depth gradient. Units for the cumulative $R, P$, and NEM measures are relative to the maximum accumulated values, with $\max =1$. The vertical reference line at $15 \mathrm{~m}$ divides the shelf into generally shallower more productive waters and deeper less productive waters

associated oxygen demand that could contribute to fueling hypoxia.

\section{Decomposition Experiments}

We conducted several decomposition experiments which were used in the development of a hypoxia budget presented in the "Discussion." Weekly and biweekly experiments were 


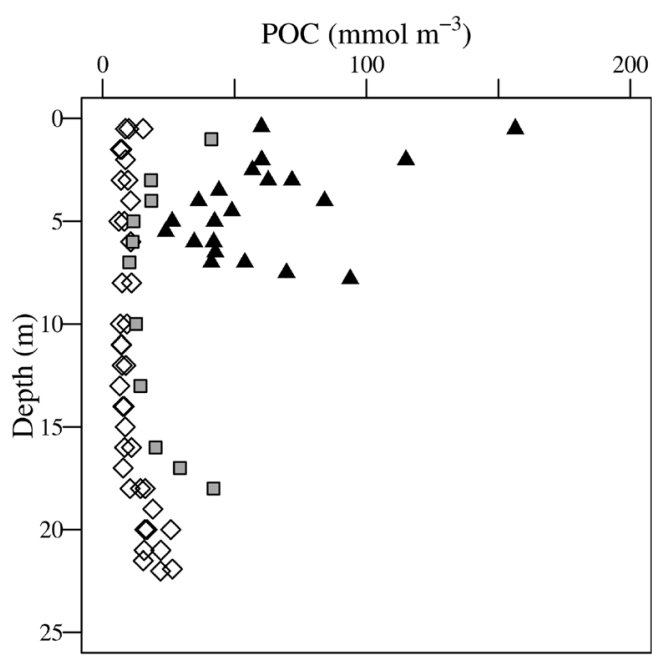

Fig. 7 Vertical profiles of POC concentrations from three stations in April 2007. Diamonds $=$ offshore station H4, squares $=$ mid-shelf station $\mathrm{C} 6$, and triangles $=$ shallow station $\mathrm{C} 2$

conducted over 2 years for estuarine and riverine samples that might contribute a mixture of fresh and aging detrital carbon to the offshore system. Results show potential carbon lability and decomposition under uniform laboratory conditions. Overall, about $16 \%$ of the carbon was potentially labile and
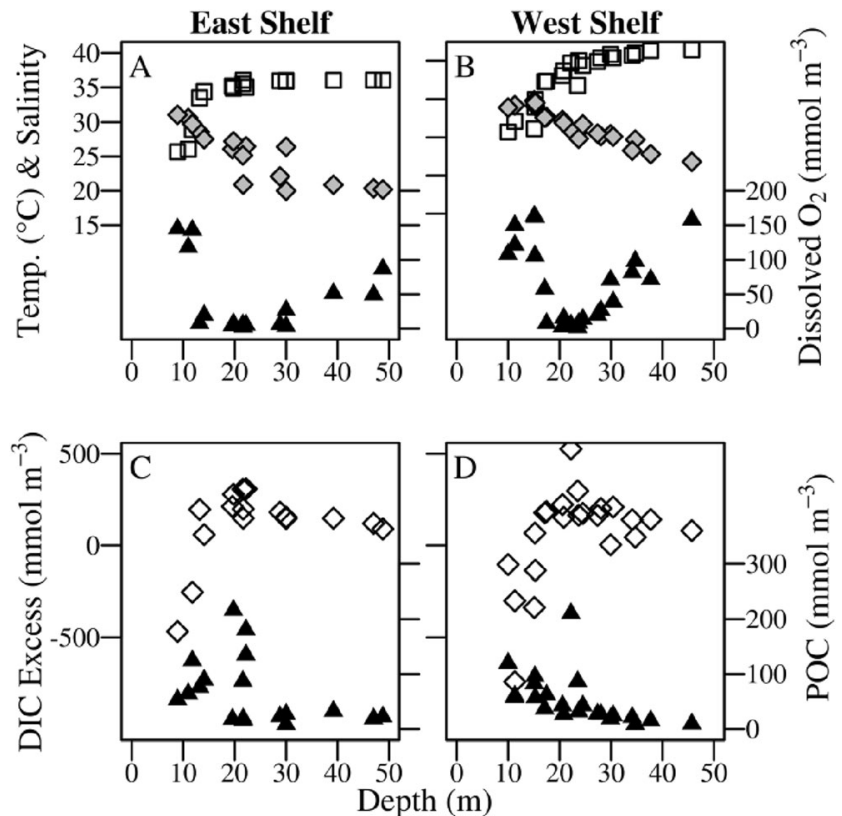

Fig. 8 Oceanographic and hypoxia-related variables for bottom waters collected in the July 2008 shelfwide cruise at increasing depths along two sets of nearshore-offshore transects. The transects were located near the mainstem Mississippi River input at Southwest Pass (left panels, representing the eastern transects bracket shown Fig. 1a) and to the southwest of the Atchafalaya River inputs (right panels, representing the western transects bracket shown Fig. 1a). a, b Salinity (squares, left axis), temperature (diamonds, left axis), and dissolved oxygen (triangles, right axis). c, d Bottom water POC (triangles, right axis) and DIC excess (diamonds, left axis; positive values indicate net heterotrophy and DIC buildup from respired $\mathrm{CO}_{2}$, negative values in shallowest waters indicate net autotrophy and photosynthetic DIC drawdown)

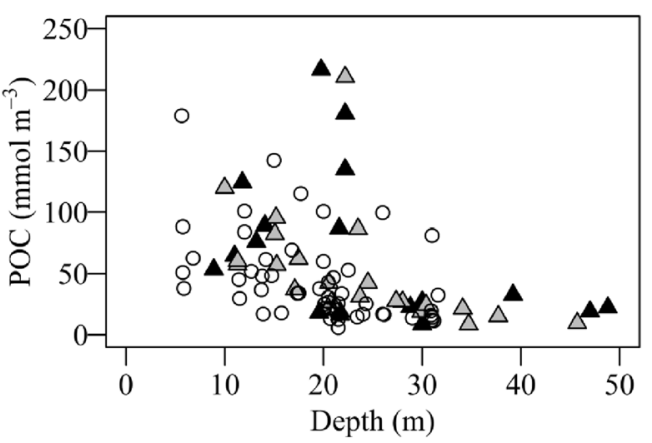

Fig. 9 Bottom water POC concentrations versus depth offshore for monthly March-August 2008 data (circles) and for 2008 shelf-wide samples collected along two sets of nearshore-offshore transects, near the mainstem Mississippi River input at Southwest Pass (black triangles, representing the eastern transect bracket shown in Fig. 1a) and to the southwest of the Atchafalaya River inputs (gray triangles, representing the western transect bracket shown in Fig. 1a)

decomposed from the DOC and POC pools during incubations, with the exception that a higher potential lability of $35 \%$ occurred for estuarine POC samples from Barataria Bay. In detail, the following lists the overall average percent potential lability for DOC and POC, with the initial and final averages_SEM $(n)$ given in units of millimoles of carbon per cubic meter: Barataria POC, $35 \%$ potential lability, 234 \pm 13 (78) and $151 \pm 8$ (78); Barataria DOC, $15 \%$ potential lability, $583 \pm 12(15 \overline{6})$ and 494+9 (156); Mississippi River POC, $15 \%$ potential lability, $\overline{260 \pm 16}(30)$ and $222 \pm 14(30)$; and Mississippi River DOC, $19 \%$ potential lability, $433+9$ (62) and $351 \pm 6(62)$.

\section{Discussion}

This 5-year study of the Louisiana shelf yielded three key findings: (1) carbon dynamics were linked closely to river nutrient inputs, (2) net carbon production predominantly occurred at low salinities and nearshore, and (3) POC concentration gradients were consistent with POC moving crossshelf from net autotrophic nearshore areas to mid-shelf heterotrophic regions, helping fuel summer hypoxia. These three results are discussed in sequence.

\section{Carbon Budget for Hypoxia}

Measurements showed a consistent picture of nutrient-linked carbon withdrawal from surface waters at low salinities, with an accompanying rise in $\mathrm{pH}$ and accumulation of POC. These features are consistent with high algal production in riverinfluenced waters, and stoichiometric calculations closely linked carbon dynamics to river nutrient (nitrate + nitrite) loading. Given these consistencies, we assembled a preliminary budget to consider whether the classic view could be correct, 
namely that nutrients alone could fuel widespread hypoxia along this coast. Although we do not have all the seasonal carbon dynamics data nor an accurate summary of all oceanographic variability needed to form a complete carbon budget for hypoxia formation on the Louisiana shelf, we found it nonetheless useful to consider preliminary values toward a budget.

First, we used the decomposition results for estuarine and river particulates to update the outwelling calculations presented in Das et al. (2010, 2011), using the $\mathrm{C} / \mathrm{N}=106 / 16$ Redfield ratio to convert inorganic nitrogen inputs to carbon units. Most terms in these calculations (Table 1) were directly taken from Das et al. (2010, 2011), with the only changes being the conversion from nitrogen to carbon units and the inclusion of the percent lability estimates from this study. The results given in Table 1 indicate that the nutrient and carbon sources for the shelf region are dominated by the Mississippi River nitrate load (95\%), with a small contribution from Mississippi River particulates (4.8\%), and a very small contribution $(0.2 \%)$ for estuarine outwelling from one of the five major estuaries along the southern Louisiana coast. Part of the reason for these low contributions from river and estuarine sources is that the potential lability experiments for river and estuarine samples showed that on average, most (65-85\%) of the combined POC and DOC pool was not labile and survived over the 28-day incubation periods. However, it is possible that the potential lability experiments underestimated the true field lability due to lack of exposure to intermittent light or other factors (Miller and Moran 1997; Del Giorgio and Davis 2003). To account for such factors in a sensitivity calculation, we assumed a $25 \%$ increase in POC lability for river and estuarine samples, but found that the dominant importance of river nutrients in Table 1 remains much the same, declining only $1 \%$ from 95 to $94 \%$. Recent budget analyses indicate that riverine DIN loading is also about eight times larger than oceanic DIN fluxes entering the offshore edge of this shelf ecosystem (Lehrter et al. 2013). If DON is also considered in these flux calculations, the relative importance of river $\mathrm{N}$ loading decreases but is still twice that of other sources (Lehrter et al. 2013).

The calculations of Table 1 and Lehrter et al. (2013) indicate an overwhelming dominance of the river nutrient load as the underlying fuel for hypoxia. This would mean that substantial nutrient reductions are needed before the true significance of other factors contributing to hypoxia can be evaluated in a meaningful way. In contrast to this perspective, studies with inverse food web models have led to the conclusion that nutrients can explain only $23 \%$ of hypoxia (as reviewed by Dagg et al. 2007). Such inverse studies often use highly underdetermined sets of equations, and for example, Breed et al. (2004) used deterministic equations for only about $30 \%$ of the 181 modeled carbon flows in their Gulf of Mexico model. Modelers recognize that these types of underdetermined inverse models have many alternate solutions (Soetaert and van Oevelen 2009), so that a $23 \%$ estimate for nutrient importance might be better regarded as one hypothesis among many. The idea that nutrients are insufficient to fuel hypoxia has led to alternate hypotheses, such as the importance of decomposing carbon deposited in hurricane layers, old peats, and lignins deposited from riverine and coastal sources (Bianchi et al. 2011). Long-term decomposition of this type has been hypothesized as one possible reason for recent trends in hypoxia intensification for the Louisiana shelf (Turner et al. 2008), but one modeling study for Chesapeake Bay indicates that this type of long-term benthic metabolism potentially accounts for only $3-15 \%$ of respiratory demand and has little overall importance in explaining hypoxia (Liu et al. 2010).
Table 1 Carbon demand exported to Louisiana shelf, updated from Das et al. (2011). For Barataria Estuary entries in column 2, positive values indicate import from the offshore shelf ecosystem and negative values indicate export from the estuary to the shelf

\begin{tabular}{llll}
\hline & $\begin{array}{l}\text { Mississippi River (MR) } \\
\text { Billion mol/year, } \\
\text { C equivalents }\end{array}$ & $\begin{array}{l}\text { Barataria Estuary (BE) } \\
\text { Billion mol/year, } \\
\text { C equivalents }\end{array}$ & BE/MR, \% \\
\hline TOC & 333.3 & -9.1 & -2.7 \\
DOC & 208.2 & -6.5 & -3.1 \\
Labile DOC & 38.0 & -0.9 & -2.4 \\
POC & 125.2 & -2.6 & -2.1 \\
Labile POC & 17.2 & -0.9 & -5.0 \\
Nitrate (as labile POC) & 342.6 & 3.3 & 1.0 \\
Total labile POC & 360.7 & & \\
\% from MR nitrate & 95.0 & & \\
\% from MR POC & 4.8 & & \\
$\%$ from BE & 0.2 & & \\
\hline
\end{tabular}


Studies in the Chesapeake Bay system indicate that mild changes in wind forcing may be responsible for recent hypoxia intensification in that system (Murphy et al. 2011). For the Louisiana shelf ecosystem, continual planktonic carbon inputs may be important in sustaining summer hypoxia, as discussed in the last section of this paper.

The river nutrient load also can be compared directly with the carbon demand to support hypoxia, though many of the numbers to complete this budgetary comparison are poorly constrained at this time. Table 2 outlines the calculations with average nitrate loads measured by Goolsby and Battaglin (2001) providing the

Table 2 Preliminary budget for sufficiency of river nitrate to sustain hypoxia on the Louisiana continental shelf. Calculations are made with nitrate currency and Redfield ratio (Redfield et al. 1963) conversions between nitrate and oxygen

(a) Oxygen demand for hypoxia

(a1) Average hypoxic area, $\mathrm{km}^{2}$ (Rabalais et al. 2010)

13,500

(a2) Vertical extent of hypoxic water, $m$

5

(a3) Volume of hypoxic water, $\mathrm{m}^{3}(=\mathrm{a} 1 \times 1,000 \times 1,000 \times$ a2)

(a4) Starting DO, mg $\mathrm{l}^{-1}$ $10^{10}$

(a5) Ending DO, mg $1^{-1}$

6

(a6) Oxygen lost to become hypoxic, $\mathrm{mg}^{-1}$ (=a4-a5)

(a7) Oxygen lost to become hypoxic, $\mathrm{mmol} \mathrm{m}^{-3}$ $(=\mathrm{a} 6 \times 1,000 / 32)$

(a8) Total oxygen lost for hypoxic volume, mol DO $(=\mathrm{a} 3 \times \mathrm{a} 7 / 1000)$

(a9) Nitrate equivalent of oxygen loss (Redfield ratio, $16 \mathrm{~N} / 138 \mathrm{DO})$, mol nitrate $(=\mathrm{a} 8 \times 16 / 138)$

(b) River supply

(b1) River nitrate load, mt nitrate-N per year (Goosby and Battaglin 2001)

(b2) River nitrate load, mol nitrate per year $(=\mathrm{b} 1 \times 1,000,000 / 14)$

1

5

156.25

$1.05 \times$ $10^{10}$

$1.22 \times 10^{9}$

$9.69 \times 10^{5}$

$6.92 \times$ $10^{10}$

(c) River supply/hypoxia demand

River nitrate supply/hypoxia nitrate demand (=b2/a9)

(d) Factors decreasing river nitrate supply to hypoxic area

(d1) Nitrate retained on shelf; the rest is exported offshore 0.7

(d2) Nitrate delivered to shelf west of Bird's

Foot Delta; the rest is delivered to the east

(d3) Nitrate delivered to central shelf hypoxic areas; the rest is delivered nearshore and offshore

(d4) Nitrate kept in the water column; the rest is denitrified in sediments

(d5) Nitrate retained to fuel phytoplankton production; the rest is grazed and lost to consumers

(e) Factors increasing hypoxia demand

(e1) number of times hypoxia is re-established per year

(f) Final, adjustments to supply/demand ratio, $=\mathrm{c} \times(\mathrm{d} 1 \times \mathrm{d} 2 \times \mathrm{d} 3 \times \mathrm{d} 4 \times \mathrm{d} 5) / \mathrm{e}$ resulting in:

Final ratio of (river nitrate supply)/(hypoxia nitrate demand) potential carbon supply for oxygen consumption in the hypoxic zone. This calculation indicates that if all nitrate were converted to phytoplankton carbon and then sedimented out and focused in the hypoxic zone where it is finally respired with oxygen, then there is a very large, 57-fold excess (Table 2, entry c) of riverine nutrients that could very easily cause hypoxia. However, this calculation is too simplistic, and consideration of additional factors can reduce this $57 \times$ factor substantially. The calculations in Table 2 (entries for factors $\mathrm{d} 1-\mathrm{d} 5)$ assumes a rather arbitrary and fixed decrease (30\% reduction) in the $57 \times$ estimate for each of the five factors in a still very preliminary budget: (1) only $70 \%$ of the river load is discharged to the southern and western Louisiana shelf, with the remainder discharged to the east; (2) only $70 \%$ of nutrients are retained with $30 \%$ exiting in surface waters off the shelf; (3) the distribution of nutrients is wider than the hypoxic shelf and $30 \%$ is distributed to nonhypoxic portions of the shelf; (4) only $70 \%$ of the nitrate survives to fuel production, with $30 \%$ denitrified before contributing to hypoxia; and (5) growth of fish and zooplankton grazers removes $30 \%$ of nitrate as consumer biomass. Lastly, the Table 2 calculations also assume that the hypoxic volume is not static but ventilated and re-established an average of 5 times per year (entry for factor e1 in Table 2). Including the effects of these six factors (Table 2, factors $\mathrm{d} 1-\mathrm{d} 5$ and e1), the result is that nutrient supply is sufficient to fuel hypoxia with a modest excess of $1.9 \times$, much reduced from the initial $57 \times$ estimate. That nutrients are slightly in excess by $1.9 \times$ but not vastly in excess by $10-100 \times$ is in line with the idea that nutrients are the main fuel for hypoxia and that substantial nutrient reductions in the 40 $70 \%$ range are likely needed to significantly reduce the size of hypoxic area to the current management target of $5,000 \mathrm{~km}^{2}$ or less (Liu et al. 2010).

The spreadsheet model calculations of Table 2 are presented mostly to make it easy to compare and update future budget estimates of hypoxia formation, as better data become available for the various terms. Dagg et al. (2007), Wang and Justić (2009), and Kim and Min (2013) provide an overview current understanding for some of the most uncertain factors in Table 2, those for grazing, export, and denitrification. For example, Wang and Justic (2009) show that south-trending river plume filaments can be observed off the mouth of the mainstem Mississippi River at Southwest Pass, with these filaments likely escaping nearshore processing and exporting phytoplankton off the shelf. This type of export is however hard to quantify so we have only included only a rough $30 \%$ export estimate in our budget (Table 2, factor d1). Calculations show that if 
these three most uncertain factors (grazing, export, and denitrification) are each decreased by $20 \%$ or alternatively each increased by $20 \%$, the final results vary between $1.0 \times$ and $3.3 \times$, respectively, rather than the $1.9 \times$ result reported in Table 2 . This variation in final $1.9 \times$ result between $1.0 \times$ and $3.3 \times$ emphasizes that the calculations in Table 2 should be regarded as preliminary at this time.

\section{Nearshore Carbon Removal}

Drawdown of DIC was evident in the shelfwide cruises (Fig. 3), and similar observations of substantial DIC drawdowns for this area in spring and summer months have been published for other years (Lohrenz and Cai 2006; Guo et al. 2012). Also, low salinity POC maxima near 15 salinity found here for 2006-2010 July cruises (Fig. 2) are very similar to maximum phytoplankton chlorophyll and productivity at 10-20 salinity observed for a July-August cruise three decades previously in 1990 (Lohrenz et al. 1999). These long-term consistencies support a picture of carbon drawdown and net ecosystem autotrophy that is undoubtedly linked to the nutrient loading from the river, with phytoplankton using available nutrients, depleting DIC pools and forming POC. Nutrient use can be estimated to occur within 1-3 days, given the high net production rates observed in river-influenced nearshore waters (Fig. 5). These rates are 5-10 times higher than the rates observed in local estuaries where phytoplankton productivity is usually light-limited (Randall and Day 1987; Madden et al. 1988; Lane et al. 2002) and probably indicate reduced light limitation in the clearer offshore waters (Lohrenz et al. 1999). Our analysis indicated that DIC removal occurs in two ways: it proceeds to a deficit consistent with the nutrient load set by the river, and it occurs with a coupled loss of POC from surface waters (Fig. 3). The POC loss from surface waters for the 2006-2010 July shelfwide cruises averaged $66 \%$ complete by a salinity of 15 , indicating removal of organic matter from surface sites of phytoplankton production and organic matter retention by the nearshore shelf ecosystem.

The DIC deficits (Fig. 3) were very consistent with complete use of river nutrients without other nutrient inputs. New production from other nonriver sources would be theoretically possible if DIN from estuarine or slope waters were added to shelf waters. But the rather conservative (straight line) dilution of the DIC deficit at higher salinities (Fig. 3) does not indicate a detectable role for DIN additions from slope waters, and one well-studied estuarine system of the area (Barataria Bay; Das et al. 2011) imports DIN rather than exporting
DIN to the offshore shelf. Most higher salinity shelf waters had nearly balanced $P$ and $R$ or were slightly heterotrophic (Fig. 6c), features that are characteristic of nutrient recycling rather than new nutrient additions. It should be noted that productivity and chlorophyll can still be high in such recycling areas (Quigg et al. 2011, Guo et al. 2012). There is also patchiness in the $P$ and $R$ dynamics evident as scatter around the middle (DIC deficit) line in Fig. 3, and it is expected for a turbulent plume system that mixes in several ways but is still river-dependent. Lastly, it may be that other nutrient sources make important contributions at the nearshore or offshore margins of the shelf ecosystem (Lehrter et al. 2013), but such effects may be lower, more diluted or more continuous, and hard to detect in comparison to the tremendous point source nutrient input from the river.

The use of salinity-property mixing models like those of Fig. 3 can be flawed especially if river sources vary markedly in time or if there are multiple freshwater sources (Loder and Reichard 1981; Regnier et al. 1998). Regarding time variation, the river source measurements used here were from the Mississippi River at Baton Rouge sampled during the July weeks preceding and at the same time as the cruises. River DIC concentrations gradually increase through the spring and summer, and for this reason, this study and a previous one (Guo et al. 2012) used only recent (preceding several weeks) data to characterize river end-members. The use of several weeks of river data in this study corresponded to the several week residence time of water on the shelf (Wiseman et al. 1997). Regarding multiple river end-members, the Atchafalaya River system is an offshoot of the mainstem Mississippi River and can have lower DIC concentrations due to inputs from the Red River in the upper Atchafalaya Basin (Guo et al. 2012). DIC concentrations estimated from long-term alkalinity measurements in the Mississippi and Atchafalaya were however generally quite similar within $10 \%$ in summer months (Guo et al. 2012). For the July 2006-2010 cruises of this study, USGS data from Melville in the upper Atchafalaya Basin showed that the Atchafalaya had $7 \%$ lower alkalinity averages than the mainstem Mississippi River, averages that were not significantly different than those in the mainstem river. Because the two arms of the river overall had similar inorganic carbon chemistries in July, we choose to use the directly measured DIC data at Baton Rouge in constructing Fig. 3, rather than using the infrequent July alkalinity measurements available from both rivers. Also, the Red River water dilutes nitrate as well as DIC (BryantMason et al. 2013), so that the calculated DIC deficits expected from nitrate use (Fig. 3, middle line) 
were not sensitive to the proportion of water from the Atchafalaya versus mainstem Mississippi River. Overall, the approach taken in Fig. 3 appeared fairly robust to known temporal and spatial changes in river end-members. However, multiple parameters (Appendix) were used in the budget calculations associated with Fig. 3, and propagation of errors led to the conclusion that although the average trends for DIC dynamics in Fig. 3 were consistent with complete nitrate + nitrite use at salinities $<20$, some nutrients $(0-25 \%)$ may survive to fuel net autotrophy in more offshore July waters.

Current models for the region off Southwest Pass depict primary productivity occurring at higher salinities of 18-30 in an extended offshore plume (Green et al. 2006; Guo et al. 2012), following ideas that river water mixes as it moves offshore into deep water and then slowly develops blooms. This would result in the DIC deficits observed above salinities of 18-20 if water is sampled a few days after mixing, i.e., bloom formation is slow relative to mixing. However, data collected in this study indicated a second possible model, that there was a large pool of low salinity water formed nearshore where bloom formation was fast relative to dilution. This type of "pool and react" model seems most applicable for the Atchafalaya system, but may also apply to the region near SW Pass where very high nearshore NEM was observed at low salinity even in 2008, a high flow year (Fig. 5a). General observations of large DIC deficits that are well-developed by salinities of 15-20 are also consistent with this model (Fig. 3).

Blooms in the region near SW Pass in the nearshore area 5$10 \mathrm{~km}$ from shore have been known for many decades (Thomas and Simmons 1960), and winds in July can act to pool rather than spread river plumes (Green et al. 2006). Additionally, oceanographic models for nearshore areas near Southwest Pass (http://pong.tamu.edu/ zhangxq/tglo.html) show low salinity pools for July 2008 and 2009 when incubations (Figs. 4, 5, and 6) showed high nearshore $P$ and $R$. Rapid phytoplankton production in such pooled river waters could be accompanied by rapid diatom sinking as observed near the mouths of other major US river systems (Chant et al. 2008; Moline et al. 2008; Kudela et al. 2010). Substantial diatom production and sinking also has been observed for the Louisiana shelf system (Redalje et al. 1994; Turner and Rabalais 1994; Fahnenstiel et al. 1996; Dortch et al. 1997, 2001) and could explain the POC retention signals seen in this study.

Some counter current or return flows may also be important in these pooled waters. There are no published reports specifically supporting this speculation about return flows at this time, although for the Amazon plume system, studies show that this type of estuarine circulation involving on-shelf, shoreward flow of subsurface water can be 10 times greater than riverine discharge (Smoak et al. 1996; Dagg et al. 2004). For the Mississippi River system, Hitchcock et al. (1997) have shown that dilution of surface river plume water occurs from below from 2 to $4 \mathrm{~m}$ depths with water $\sim 25$ salinity. If this higher salinity water were recirculating from nearby pooled sources, the $\mathrm{pH}$ and POC maxima (Figs. 2 and 3) and DIC minima (Fig. 3) observed here at 10-20 salinities would arise, and nutrient regeneration and upward mixing of especially phosphorous (Sylvan and Ammermann 2013) from returning waters could support the observed DIC depletion and inferred complete DIN use (Fig. 3). Regeneration of nutrients from sediments may also be involved in phosphorous resupply that enables nitrate + nitrite consumption in well-mixed nearshore waters.

It is also evident that the plume off of Southwest Pass can swing widely somewhat like a loose fire hose and force river water past any nearshore pools (Fig. 11 in Wang and Justić 2009). For example, southeasterly winds prevalent in summer can favor pooling of river water near the delta, but northeasterly winds that are more prevalent in winter and spring can guide the plume westward away from the delta (Justić and Wang 2009). Thus, although both nearshore and offshore net autotrophy can be important in this large system, nearshore net autotrophy may be more dominant during the summer hypoxia season. Net heterotrophy characterized surface waters of much of the deeper offshore shelf system in the July shelfwides (Fig. 6c), in agreement with other recent estimates (Murrell and Lehrter 2011; Murrell et al. 2013).

\section{Cross-Shore Forcing of Hypoxia}

Overall, the carbon and oxygen field measurements agreed well to show a recurring system of net autotrophic productivity operating along the inner July shelf. The summer shelfwide studies detailed here point toward a possible nearshore-offshore or cross-shore conceptualization of hypoxia dynamics, with fluxes of nearshore carbon fueling adjacent hypoxia zones located just offshore. This is in contrast to studies that have a more along-shelf or east-to-west focus reflecting mostly springtime conditions when river water often spreads broadly westwards over the shelf (Rowe and Chapman 2002; Scavia et al. 2003). It seems likely that both cross-shelf and along-shelf components are important for hypoxia (Boesch 2003; Walker and Rabalais 2006; DiMarco et al. 2010), but measurements of bottom water POC made in this study were more consistent with the cross-shelf model. Especially monthly data 
collected in 2008 (Fig. 9) indicated that about $90 \%$ of observations along the $\mathrm{C}$ transect of the central shelf were consistent with the cross-shelf model during March-August, with only a few observations (6 \% of all data or $15 \%$ of the shelfwide-only data, Fig. 9) showing inputs consistent with mid-shelf rain of organic matter expected from an along-shelf model. Although lateral POC fluxes from nearshore to mid-shelf hypoxic waters might seem slow and diffuse, once this POC has entered hypoxic waters, it may persist and spread for longer periods of time. This is because low oxygen in hypoxic bottom waters prevents rapid consumption of sedimented POC (Fig. 7 in Murrell and Lehrter 2011), with the consequence that hypoxic waters are storing carbon fuel and oxygen demand. Our decomposition experiments indicated phytoplankton was mostly mineralized within 1 week under fully oxic conditions, but the experiments of Murrell and Lehrter (2011) indicated that especially in low oxygen conditions, decomposition may proceed more slowly over multiple weeks. Further detailed experiments on plankton decomposition rates under low oxygen conditions are needed.

In addition to resuspension (Xu et al. 2011) moving POC seaward from nearshore productive zones into mid-shelf hypoxic areas, other mechanisms can transport carbon offshore. For example, surface waters of the nearshore Louisiana coastal current occasionally spread over the middle shelf (Wiseman et al. 1997), and production sedimenting from this current system could help fuel hypoxia. Also, water movements in mid-depth layers are not uncommon in this shelf ecosystem (Wiseman and Kelly 1994; Wiseman et al. 1997, 2004) and could potentially contribute to offshore carbon transport and to mid-depth productivity (Lehrter et al. 2009) fueled by nutrients regenerated in shallow nearshore waters. These types of cross-shelf dynamics are common for shelf ecosystems (Martinez-Lopez and Zavala-Hidalgo 2009; Lentz and Fewings 2012; Lehrter et al. 2012). Cross-shelf patterning is also evident in other recent studies of the Louisiana shelf ecosystem (Cai et al. 2011; Lehrter et al. 2012; Murrell et al. 2013).

Finally, the interface between nearshore and mid-shelf waters (Fig. 8) may be an area of important respiration for POC moving offshore, and this interface could shield the midshelf waters from lateral reoxygenation events originating in the shallow nearshore waters. The interface itself may thus have some importance for overall sustenance of hypoxia, while mobile POC moving across the shelf from nearshore waters may be more important in hypoxia generation and sustenance. These ideas need more quantitative testing and modeling in future studies. In such studies, more emphasis could be given to shallow nearshore waters that are traditionally undersampled. This study identifies these areas as net autotrophic (Figs. 3 and 6c) source regions that are exporting carbon as POC along bottom gradients (Figs. 8 and 9) to adjacent mid-shelf hypoxic waters. The actual cross-shelf fluxes of POC remain to be quantified in future studies.

\section{Conclusions}

There has been a long-term scientific effort over several decades to observe and model the Mississippi River influences on the Louisiana shelf and hypoxia. This ecosystem is well-studied, so it is important to consider the new perspectives gained from this study conducted over 5 years. The results of this study provided two substantial shifts in the way this shelf ecosystem can be understood. First, net autotrophy was measured in the field with DIC deficits, $\mathrm{pH}$, and POC assays and also in shipboard oxygen incubations, with all field and laboratory measures agreeing and showing that new production happens predominantly at low salinities $<15$ and nearshore. This shifts the focus of net carbon production from extended offshore plumes (Lohrenz et al. 1999; Wang and Justić 2009) to the nearshore regions of the Louisiana coastal current (Wiseman and Kelly 1994; Wiseman et al. 1997, 2004) where chlorophyll levels are highest in this shelf system (Walker and Rabalais 2006; Fennel et al. 2011). Murrell et al. (2013) have also recently highlighted the possible importance of these nearshore waters for hypoxia. The net autotrophy measurements reported here agree in principle with those conclusions and show that these near-river and nearshore areas are net source regions for carbon fueling hypoxia. The second shift is that the carbon transport system is taking place in subsurface waters. Most of the net POC production is rapidly lost from the surface mixed layer in these nearshore and low salinity zones, and carbon transport to hypoxic zones is by mid-layer and bottom layer mechanisms. In this regard, the quiet stratified waters of the mid-shelf likely form an efficient trap for carbon produced in the more turbulent nearshore waters. We do not yet know the details of the transport and trapping processes, but these processes are gaining increasing attention (Xu et al. 2011). In summary, the two shifts in understanding identified here for carbon production and for carbon transport could be considered preliminary in that there is not yet decadal-level research solidly supporting these ideas. In this situation, testing the details of the possible cross-shelf feeding of hypoxia may be fruitful in the coming years.

Acknowledgments The captain and crew of the R.V. Pelican and Anandita Das helped in collecting the shelfwide samples. Charles S. Milan performed the nutrient analyses. EPA scientists and the captain and crew of the O.S.V. Bold made possible high-resolution studies of POM composition during April 2007. This work was supported by NOAA MULTISTRESS award 16OP2670, by NOAA Coastal Ocean Program grants NA06NOS4780141 and NA09NOS4780204, and NOAA grant 412 NA06OAR4320264 06111039 to the Northern Gulf Institute. This is a CSCOR NGOMEX09 publication no. 197. 
Table 3 End-member values for river-ocean mixing. Values are means $+\operatorname{SEM}(n)$

\begin{tabular}{|c|c|c|c|c|c|c|c|c|}
\hline Time & $\begin{array}{l}\text { River } \\
\text { salinity (psu) }\end{array}$ & $\begin{array}{l}\text { River DIC } \\
\left(\mathrm{mmol} \mathrm{m}^{-3}\right)\end{array}$ & $\begin{array}{l}\text { River POC } \\
\left(\mathrm{mmol} \mathrm{m}^{-3}\right)\end{array}$ & $\begin{array}{l}\text { River DIN } \\
\left(\mathrm{mmol} \mathrm{\textrm {m } ^ { - 3 }}\right)\end{array}$ & $\begin{array}{l}\text { Ocean } \\
\text { salinity (psu) }\end{array}$ & $\begin{array}{l}\text { Oceanic DIC } \\
\left(\mathrm{mmol} \mathrm{m}^{-3}\right)\end{array}$ & $\begin{array}{l}\text { Oceanic POC } \\
\left(\mathrm{mmol} \mathrm{m}^{-3}\right)\end{array}$ & $\begin{array}{l}\text { Oceanic DIN } \\
\left(\mathrm{mmol} \mathrm{m}^{-3}\right)\end{array}$ \\
\hline July 2008 & 0.4 & $2,784 \pm 104$ & & $145 \pm 8(4)$ & $35.58 \pm 0.06(5)$ & $2,169 \pm 24(5)$ & $10 \pm 2(5)$ & 0 \\
\hline July 2009 & 0.4 & $2,697 \pm 91(2)$ & & $135 \pm 6(4)$ & $35.49 \pm 0.16(4)$ & $2,134 \pm 41(4)$ & $16 \pm 5$ & 0 \\
\hline Average & 0.4 & 2,741 & 13 & 140 & 35.54 & 2,151 & 13 & 0 \\
\hline
\end{tabular}

\section{Appendix}

End-member values and AZE calculations associated with Fig. 3

The detailed end-member values used in constructing Fig. 3 are summarized in the following table and text.

The detailed river end-member data used in Fig. 3 were averages of the July samples taken at Baton Rouge, with respective 2008 and 2009 means in millimoles per cubic meter + SEM $(n)$ of 2,784+104 (4) and 2,697+91 (2) for DIC and $145 \pm 8$ (4) and $135 \pm 6$ (4) for nitrate+nitrite. The DIC deficit expected at 0 salinity if all nitrate + nitrite reacted was calculated assuming that phytoplankton growth was responsible for the deficit, with $85 \%$ of DIC removal occurring to $\mathrm{POC}$ at the molar $\mathrm{C} / \mathrm{N}$ Redfield ratio of 6.625 (Redfield et al. 1963) and the remaining $15 \%$ (O'Reilly et al. 1987) of $\mathrm{DIC}$ forming $\mathrm{DOC}$ with a $\mathrm{C} / \mathrm{N}$ ratio of 15 for mid-salinity summer river plume samples for this area (Table 2 in Pakulski et al. 2000; Table 4 in Benner and Opsahl 2001). DOC measurements made for samples collected during a July 2011 shelfwide cruise (data not shown) indicated a DOC excess of 100-200 $\mathrm{mmol} \mathrm{m}^{-3}$, in agreement with expectations that DOC accounted for about $15 \%$ of total DIC removal.

Similarly, the POC expected at 0 salinity if nitrate + nitrite reaction was complete assumed $85 \%$ of DIC removal to POC occurring with the molar $\mathrm{C} / \mathrm{N}$ Redfield ratio of 6.625. A value of $13 \mathrm{mmol} \mathrm{m}^{-3}$ representing estimated July Mississippi River POC (Fig. 2) was added to this value based on nitrate + nitrite consumption. Overall, calculations were done separately for 2008 and 2009 end-member values, then averaged to obtain values shown in Fig. 3. These averaged July river endmembers in millimoles of carbon per cubic meter are 2,741 for DIC, 1,638 for DIC if all nitrate+ nitrite reacts, and 801 for POC. The value of $801 \mathrm{mmol} \mathrm{m}^{-3}$ for POC after phytoplankton growth includes a baseline July estimate of $13 \mathrm{mmol} \mathrm{m}^{-3}$ for riverine POC obtained from low salinity samples collected during the shelfwide cruises (Fig. 2). The most important error associated with this end-member POC estimate of $801 \mathrm{mmol} \mathrm{m}^{-3}$ stems from the variability in nitrate + nitrite concentrations, with SEM values in 2008 and 2009 of 8 and $3 \mathrm{mmol} \mathrm{m}^{-3}$ in these nitrogen measurements corresponding to a POC variability of 88 and $31 \mathrm{mmol} \mathrm{m}^{-3}$, or an average of
+60 for the river end-member shown in the bottom line of Fig. 3. This variability is relatively small, about $\pm 7 \%$ of the POC signal, so that the calculations of POC removal given in the "Results" are fairly well constrained. The errors given for percent removed in the "Results" reflect the variability only in the measured POC concentration data, not the propagated error including end-members.

The offshore end-members in Fig. 3 were obtained by averaging results for high salinity $(>35)$ samples, with 2008 and 2009 respective means + SEM $(n)$ of $35.58 \pm 0.06(5)$ and $35.49 \pm 0.16$ (4) for salinity, $2,169 \pm 24$ (5) and $\overline{2}, 134 \pm 41$ (4)

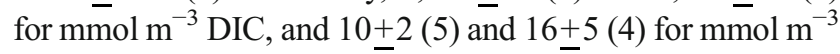
POC. The offshore end-members used in Fig. 3 were averages of these 2 years, $2,151 \mathrm{mmol} \mathrm{m}^{-3}$ DIC and $13 \mathrm{mmol} \mathrm{m}^{-3}$ POC at a salinity of 35.5 .

For DIC data of 2008 and 2009 (Fig. 3), we used the AZE method critically reviewed by Regnier et al. (1998) to backextrapolate the apparent 0 salinity river DIC end-member using the higher salinity data (open triangles in Fig. 3). The linear regression extending back from the high salinity data to 0 salinity had a DIC intercept value of 1,697 \pm 32 (standard deviation) $\mathrm{mmol} \mathrm{m}^{-3}$, with the intercept error calculated in the statistical package in $\mathrm{R}$ (The $\mathrm{R}$ Project for Statistical Computing). This value is $59 \mathrm{mmol} \mathrm{m}^{-3}$ higher than the 1,638-mmol- $\mathrm{m}^{-3}$ value estimated above for complete nitrate + nitrite use and shown in Fig. 3 as the $y$-intercept of the middle line. However, this difference is small (only about $5 \%$ ) in terms of the total DIC drawdown near $1,100 \mathrm{mmol} \mathrm{m}^{-3}$ for these two 0 salinity scenarios where measured river DIC averaged $2,741 \mathrm{mmol} \mathrm{m}^{-3}$ for $2008+2009$ (Fig. 3). The difference between 1,697 and $1,638 \mathrm{mmol} \mathrm{m} \mathrm{m}^{-3}$ may be regarded as not significantly different due to various errors, but also may reflect some net respiration of POC and DOC carried in by river water. According to decomposition experiments for potential lability, on average 17 and $38 \mathrm{mmol} \mathrm{m}^{-3}$ riverine POC and DOC, respectively, were metabolized in month-long experiments (Table 1). Respiration of these materials would return DIC to the shelf waters, elevating the 1,638 value 0 salinity value expected from complete nitrate + nitrite use to $1,693 \mathrm{mmol} \mathrm{m}^{-3}$, a value that is virtually identical to the measured 1,697-mmol$\mathrm{m}^{-3}$ AZE value. 


\section{References}

APHA. 1989. Standard methods for the examination of water and wastewater, APHA (American Public Health Association), Washington, DC.

APHA, Eaton A.D., L.S. Clesceri, and A.E. Greenberg. 2005. Standard methods for the examination of water and wastewater. American Public Health Association (APHA, AWWA, WEF), Washington, DC.

Baustian, M.M., N.N. Rabalais, W.L. Morrison, and R.E. Turner. 2011. Seasonal microphytobenthos on the hypoxic northern Gulf of Mexico continental shelf. Marine Ecology Progress Series 436: 51-66.

Benner, R., and S. Opsahl. 2001. Molecular indicators of the sources and transformations of dissolved organic matter in the Mississippi river plume. Organic Geochemistry 32: 597-611.

Bianchi, T.S., S.F. DiMarco, J.H. Cowan Jr., R.D. Hetland, P. Chapman, J.W. Day, and M.A. Allison. 2010. The science of hypoxia in the Northern Gulf of Mexico: a review. Science of the Total Environment 408: 1471-1484.

Bianchi, T.S., L.A. Wysocki, K.M. Schreiner, T.R. Filley, D.R. Corbett, and A.S. Kolker. 2011. Sources of terrestrial organic carbon in the Mississippi plume region: evidence for the importance of coastal marsh inputs. Aquatic Geochemistry 17: 431-456.

Boesch, D.F. 2003. Continental shelf hypoxia: some compelling answers. Gulf of Mexico Science 21: 202-205.

Breed, G.A., G.A. Jackson, and T.L. Richardson. 2004. Sedimentation, carbon export and food web structure in the Mississippi River plume described by inverse analysis. Marine Ecology Progress Series 278: $35-51$.

BryantMason, A., Y.J. Xu, and M. Altabet. 2013. Isotopic signature of nitrate in river waters of the lower Mississippi and its distributary, the Atchafalaya. Hydrological Processes 27: 2840-2850.

Cai, W.-J., X. Guo, C.-T.A. Chen, M. Dai, L. Zhang, W. Zhai, S.E. Lohrenz, K. Yin, P.J. Harrison, and Y. Wang. 2008. A comparative overview of weathering intensity and $\mathrm{HCO}_{3}{ }^{-}$flux in the world's major rivers with emphasis on the Changjiang, Huanghe, Zhujiang (Pearl) and Mississippi Rivers. Continental Shelf Research 28: $1538-1549$

Cai, W.-J., X. Hu, W.-J. Huang, M.C. Murrell, J.C. Lehrter, S.E. Lohrenz, W.-C. Chou, W. Zhai, J.T. Hollibaugh, Y. Wang, P. Zhao, X. Guo, K. Gunderson, M. Dai, and G.-C. Gong. 2011. Acidification of subsurface coastal waters enhanced by eutrophication. Nature Geoscience 4: 766-70.

Carman, K.A., and B. Fry. 2002. Small-sample methods for $\delta^{13} \mathrm{C}$ and $\delta^{15} \mathrm{~N}$ analysis of the diets of marsh meiofaunal species using naturalabundance and tracer-addition isotope techniques. Marine Ecology Progress Series 240: 85-92.

Chant, R.J., S.M. Glenn, E. Hunter, J. Kohut, R.F. Chen, R.W. Houghton, J. Bosch, and O. Schofield. 2008. Bulge formation of a buoyant river outflow. Journal of Geophysical Research 113: art. C01017, doi:10. 1029/2007JC004100.

Chen, X., S.E. Lohrenz, and D.A. Wiesenbug. 2000. Distribution and controlling mechanisms of primary production on the LouisianaTexas continental shelf. Journal of Marine Systems 25: 179-207.

Coffin, R., B. Fry, B. Peterson, and R.T. Wright. 1989. Carbon isotopic compositions of estuarine bacteria. Limnology and Oceanography 34: $1305-1310$

Czaya, E. 1981. Rivers of the world. New York: Van Nostrand Reinhold Company.

Dagg, M.J., R. Benner, S. Lohrenz, and D. Lawrence. 2004. Transformation of dissolved and particulate materials on continental shelves influenced by large rivers: plume processes. Continental Shelf Research 24: 833-858.

Dagg, M.J., J.W. Ammerman, R.M.W. Amon, W.S. Gardner, R.E. Green, and S.E. Lohrenz. 2007. A review of water column processes influencing hypoxia in the Northern Gulf of Mexico. Estuaries and Coasts 30: 735-752.
Dai, Z., J. Du, X. Zhang, N. Su, and J. Li. 2011. Variation of riverine material loads and environmental consequences on the Changjiang (Yangtze) estuary in recent decades (1955-2008). Environmental Science and Technology 45: 223-227.

Dale, V.H., C. Kling, J.L. Meyer, J. Sanders, H. Stallworth, T. Armitage, D. Wangsness, T. Bianchi, A. Blumberg, W. Boynton, D.J. Conley, W. Crumpton, M. David, D. Gilbert, R.W. Howarth, R. Lowrance, K. Mankin, J. Opaluch, H. Paerl, K. Reckhow, A.N. Sharpley, T.W. Simpson, C.S. Snyder, and D. Wright. 2009. Hypoxia in the northern Gulf of Mexico. Springer Series on Environmental Management. New York: Springer.

Das, A., D. Justić, and E. Swenson. 2010. Modeling estuarine-shelf exchanges in a deltaic estuary: implications for coastal carbon budgets and hypoxia. Ecological Modelling 221: 978-985.

Das, A., D. Justić, E. Swenson, R.E. Turner, M. Inoue, and D. Park. 2011. Coastal land loss and hypoxia: the 'outwelling' hypothesis revisited. Environmental Research Letters 6: 025001. doi:10. 1088/1748-9326/6/2/025001.

Del Giorgio, P.A., and J. Davis. 2003. Patterns in dissolved organic matter lability and consumption across aquatic ecosystems. In Aquatic ecosystems: interactivity of dissolved organic matter, ed. S. Findlay and R.L. Sinsabugh, 399-424. San Diego CA: Academic Press.

DiMarco, S.F., P. Chapman, N. Walker, and R.D. Hetland. 2010. Does local topography control hypoxia on the eastern Texas-Louisiana shelf? Journal of Marine Systems 80: 25-35.

Dinnel, S.P., and W.J. Wiseman Jr. 1986. Fresh water on the Louisiana and Texas shelf. Continental Shelf Research 6: 765-784.

Dortch, Q., R. Robichaux, S. Pool, D. Milsted, G. Mire, N.N. Rabalais, T.M. Soniat, G.A. Fryxell, R.E. Turner, and M.L. Parsons. 1997. Abundance and vertical flux of Pseudonitzschia in the northern Gulf of Mexico. Marine Ecology Progress Series 146: 249-264.

Dortch, Q., N.N. Rabalais, R.E. Turner, and N.A. Qureshi. 2001. Impacts of changing $\mathrm{Si} / \mathrm{N}$ ratios and phytoplankton species composition, p. 3748. In N.N. Rabalais, and R.E. Turner (eds.), Coastal hypoxia: consequences for living resources and ecosystems. Coastal and Estuarine Studies, 58. American Geophysical Union, Washington D.C.

Etter, P.C., M.K. Howard, and J.D. Cochrane. 2004. Heat and freshwater budgets of the Texas-Louisiana shelf. Journal of Geophysical Research 109(C2): 1-23.

Fahnenstiel, G.L., M.J. McCormick, G.A. Lang, D.G. Redalje, S.E. Lohrenz, M. Markowitz, B. Wagoner, and H.J. Carrick. 1996. Taxon-specific growth and loss rates for dominant phytoplankton populations from the northern Gulf of Mexico. Marine Ecology Progress Series 117: 229-239.

Fennel, K., R. Hetland, Y. Feng, and S. DiMarco. 2011. A coupled physical-biological model of the Northern Gulf of Mexico shelf: model description, validation and analysis of phytoplankton variability. Biogeosciences 8: 1881-1899.

Goolsby, D.A., and W.A. Battaglin. 2001. Long-term changes in concentrations and flux of nitrogen in the Mississippi River Basin, USA. Hydrologic Processes 15: 1209-1226.

Green, R.E., T.S. Bianchi, M.J. Dagg, N.D. Walker, and G.A. Breed. 2006. An organic carbon budget for the Mississippi River turbidity plume, and plume contributions to air-sea $\mathrm{CO}_{2}$ fluxes and bottom water hypoxia. Estuaries 29: 579-597.

Grippo, M.A., J.W. Fleeger, N.N. Rabalais, R. Condrey, and K.R. Carman. 2010. Contribution of phytoplankton and benthic microalgae to inner shelf sediments of the north-central Gulf of Mexico. Continental Shelf Research 5: 456-466.

Guo, X., W.-J. Cai, W.-J. Huang, Y. Wang, F. Chen, M.C. Murrell, S.E. Lohrenz, L.-Q. Jiang, M. Dai, J. Hartmann, Q. Lin, and R. Culp. 2012. Carbon dynamics and community production in the Mississippi River plume. Limnology and Oceanography 57: 1-17. 
Hetland, R.D., and S.F. DiMarco. 2008. How does the character of oxygen demand control the structure of hypoxia on the TexasLouisiana continental shelf? Journal of Marine Systems 70: 49-62.

Hitchcock, G.L., W.J. Wiseman Jr., W.C. Boicourt, A.J. Mariano, N. Walker, T.A. Nelsen, and E. Ryan. 1997. Property fields in an effluent plume of the Mississippi river. Journal of Marine Systems 12: 109-126.

Justić, D., N.N. Rabalais, and R.E. Turner. 1996. Effects of climate change on hypoxia in coastal waters: A doubled CO scenario for the northern Gulf of Mexico. Limnology and Oceanograpy 41: 992-1003.

Justić, D., N.N. Rabalais, and R.E. Turner. 2002. Modeling the impacts off decadal changes in riverine nutrient fluxes on coastal eutrophication near the Mississippi River Delta. Ecological Modelling 152: 33-46.

Justić, D., V.J. Bierman, D. Scavia, and R.D. Hetland. 2007. Forecasting Gulf's hypoxia: the next 50 years? Estuaries and Coasts 30: 791-801.

Kim, I.-N., and D.-H. Min. 2013. Temporal variation of summertime denitrification rates in the Texas-Louisiana inner shelf region in the Gulf of Mexico: a modelling approach using the extended OMP analysis. Continental Shelf Research 66: 49-57.

Kudela, R.M., A.R. Horner-Devine, N.S. Banas, B.M. Hickey, T.D. Peterson, R.M. McCabe, E.J. Lessard, E. Frame, K.W. Bruland, D.A. Jay, J.O. Peterson, W.T. Peterson, P.M. Kosro, S.L. Palacios, M.C. Lohan, and E.P. Dever. 2010. Multiple trophic levels fueled by recirculation in the Columbia River plume. Geophysical Research Letters 37: L18607. doi:10.1029/2010GL044342.

Lane, R.R., J.W. Day, B. Marx, E. Reyes, and G.P. Kemp. 2002. Seasonal and spatial water quality changes in the outflow plume of the Atchafalaya River, Louisiana, USA. Estuaries 25: 30-42.

Lehrter, J.C., M.C. Murrell, and J.C. Kurtz. 2009. Interactions between freshwater input, light, and phytoplankton dynamics on the Louisiana continental shelf. Continental Shelf Research 29: 1861-1872.

Lehrter, J.C., D.L. Beddick Jr., R. Devereux, D.F. Yates, and M.C. Murrell. 2012. Sediment-water fluxes of dissolved inorganic carbon, $\mathrm{O}_{2}$, nutrients, and $\mathrm{N}_{2}$ from the hypoxic region of the Louisiana continental shelf. Biogeochemistry 109: 233-252.

Lehrter, J.C., D.S. Ko, M.C. Murrell, J.D. Hagy, B.A. Schaeffer, R.M. Greene, R.W. Gould, and B. Penta. 2013. Nutrient distributions, transports and budgets on the inner margin of a river-dominated continental shelf. Journal of Geophysical Research: Oceans 188(117): 2013. doi:10.1002/jgrc.20362.

Lentz, S.J., and M.R. Fewings. 2012. The wind- and wave-driver innershelf circulation. Annual Review of Marine Science 4: 317-343.

Liu, Y., M.A. Evans, and D. Scavia. 2010. Gulf of Mexico hypoxia: exploring increasing sensitivity to nitrogen loads. Environmental Science and Technology 44: 5836-5841.

Loder, T.C., and R.P. Reichard. 1981. The dynamics of conservative mixing in estuaries. Estuaries 4: 64-69.

Lohrenz, S.E., and W.-J. Cai. 2006. Satellite ocean color assessment of air-sea fluxes of $\mathrm{CO} 2$ in a river-dominated coastal margin. Geophysical Research Letters 33: art. L01601, doi:10.1029/ 2005GL023942, 2006.

Lohrenz, S.E., G.L. Fahnenstiel, D.G. Redalje, G.A. Lang, M.J. Dagg, and Q. Dortch. 1999. Nutrients, irradiance, and mixing as factors regulating primary production in coastal waters impacted by the Mississippi River plume. Continental Shelf Research 19: 1113-1141.

Madden, C.J., J.W. Day Jr., and J.M. Randall. 1988. Freshwater and marine coupling in estuaries of the Mississippi River deltaic plain. Limnology and Oceanography 33: 982-1004.

Martinez-Lopez, B., and J. Zavala-Hidalgo. 2009. Seasonal and interannual variability of cross-shelf transports of chlorophyll in the Gulf of Mexico. Journal of Marine Systems 77: 1-20.

Miller, W.L., and M.A. Moran. 1997. Interaction of photochemical and microbial processes in the degradation of refractory dissolved organic matter from a coastal marine environment. Limnology and Oceanography 42: 1317-1324.

Moline, M.A., T.K. Frazer, R. Chant, S. Glenn, C.A. Jacoby, J.R. Reinfelder, J. Yost, M. Zhou, and O. Schofield. 2008. Biological responses in a dynamic buoyant river plume. Oceanography 21: 70 89.

Murphy, R.R., W.M. Kemp, and W.P. Ball. 2011. Long-term trends in Chesapeake Bay seasonal hypoxia, stratification, and nutrient loading. Estuaries and Coasts 34: 1293-1309.

Murrell, M.C., and J.C. Lehrter. 2011. Sediment and lower water column oxygen consumption in the seasonally hypoxic region of the Louisiana Continental Shelf. Estuaries and Coasts 34: 912-924.

Murrell, M.C., R.S. Stanley, J.C. Lehrter, and J.D. Hagy. 2013. Plankton community respiration, net ecosystem metabolism, and oxygen dynamics on the Louisiana continental shelf: implications for hypoxia. Continental Shelf Research 52: 27-38.

O'Reilly, J.E., C. Evans-Zetlin, and D.A. Busch. 1987. Primary production, p.220-223. In R.H. Backus and D.W. Bourne (eds.), Georges Bank. Cambridge, Massachusetts: MIT Press.

Ogura, N. 1972. Rate and extent of decomposition of dissolved organic matter in surface seawater. Marine Biology 13: 89-93.

Osterman, L.E., R.Z. Poore, and P.W. Swarzenski. 2008. The last 1000 years of natural and anthropogenic low-oxygen bottom water on the Louisiana shelf. Marine Micropaleontology 66: 291-303.

Osterman, L.E., R.Z. Poore, P.W. Swarzenski, D.B. Senn, and S.F. DiMarco. 2009. The 20th-century development and expansion of Louisiana shelf hypoxia, Gulf of Mexico. Geo-Marine Letters 29: 405-414

Pakulski, J.D., R. Benner, T. Whitledge, R. Amon, B. Eadie, L. Cifuentes, J. Ammerman, and D. Stockwell. 2000. Microbial metabolism and nutrient cycling in the Mississippi and Atchafalaya River plumes. Estuarine, Coastal and Shelf Science 50: 173-184.

Quigg, A., J.B. Sylvan, A.B. Gustafson, T.R. Fisher, R.L. Oliver, S. Tozzi, and J.W. Ammerman. 2011. Going West: Nutrient limitation of primary production in the Northern Gulf of Mexico and the importance of the Atchafalaya River. Aquatic Geochemistry 17:519-544.

Rabalais, N.N., R.E. Turner, and W.J. Wiseman Jr. 2002. Gulf of Mexico hypoxia, a.k.a "The Dead Zone". Annual Review of Ecology and Systematics 33: 235-263.

Rabalais, N.N., R.E. Turner, B.K. SenGupta, D.F. Boesch, P. Chapman, and M.C. Murrell. 2007. Hypoxia in the Northern Gulf of Mexico: does the science support the plan to reduce, mitigate, and control hypoxia? Estuaries and Coasts 30: 753-772.

Rabalais, N.N., R.J. Diaz, L.A. Levin, R.E. Turner, D. Gilbert, and J. Zhang. 2010. Dynamics and distribution of natural and humancaused hypoxia. Biogeosciences 7: 585-619.

Rabalais, N.N., W.J. Cai, J. Carstensen, D.J. Conley, B. Fry, X. Hu, Z. Quinones-Rivera, R. Rosenberg, C.P. Slomp, R.E. Turner, M. Voss, B. Wissel, and J. Zhang. 2014. Eutrophication-driven deoxygentation in the coastal ocean. Oceanography 27: 172-183.

Randall, J.M., and J.W. Day Jr. 1987. Effects of river discharge and vertical circulation on aquatic primary production in a turbid Louisiana (USA) estuary. Netherlands Journal of Sea Research 21: 231-242.

Redalje, D.G., S.E. Lohrenz, and G.L. Fahnenstiel. 1994. The relationship between primary production and the vertical export of particulate organic matter in a river-impacted coastal ecosystem. Estuaries 17: 829-838.

Redfield, A.B., Ketchum, and F. Richards. 1963. The influence of organisms on the composition of sea water. In The sea, ed. M.N. Hil, 26 77. New York: Wiley-Interscience.

Regnier, P., A. Mouchet, R. Wollast, and F. Ronday. 1998. A discussion of methods for estimating residual fluxes in strong tidal estuaries. Continental Shelf Research 18: 1543-1571.

Roberts, H.H. 1998. Delta switching: early responses to the Atchafalaya River diversion. Journal of Coastal Research 14: 882-899.

Rowe, G.T., and P. Chapman. 2002. Continental shelf hypoxia: some nagging questions. Gulf of Mexico Science 2002: 153-160.

Scavia, D., and K.A. Donnelly. 2007. Reassessing hypoxia forecasts for the Gulf of Mexico. Environmental Science and Technology 41: $8111-8117$. 
Scavia, D., N.N. Rabalais, R.E. Turner, D. Justić, and W.J. Wiseman Jr. 2003. Predicting the response of Gulf of Mexico hypoxia to variations in Mississippi River nitrogen load. Limnology and Oceanography 48: 951-956.

Scavia, D., D. Justić, and V.J. Bierman. 2004. Reducing hypoxia in the Gulf of Mexico: advice from three models. Estuaries 27: 419-425.

Smoak, J.M., D.J. DeMaster, S.A. Kuehl, R.H. Pope, and B.A. McKee. 1996. The behavior of particle-reactive tracers in a high turbidity environment: ${ }^{234} \mathrm{Th}$ and ${ }^{210} \mathrm{~Pb}$ on the Amazon continental shelf. Geochimica et Cosmochimica Acta 60: 2123-2137.

Soetaert, K., and D. van Oevelen. 2009. Modeling food web interactions in benthic deep-sea ecosystems: a practical guide. Oceanography 22: $128-143$.

Sylvan, J.B., and J.W. Ammermann. 2013. Seasonal distributions of organic nutrients on the Louisiana continental shelf and their implications for nutrient limitation and hypoxia formation. Marine Chemistry 154: 113-123.

Sylvan, J.B., A. Quigg, S. Tozzi, and J.W. Ammerman. 2011. Mapping phytoplankton community physiology on a river impacted continental shelf: testing a multifaceted approach. Estuaries and Coasts 34: $1220-1233$

Thomas, W.H., and E.G. Simmons. 1960. Phytoplankton production in the Mississippi River delta, p. 103-116. In F.P. Shepard, F.B. Phleger, and J.H. van Andel (eds.), Recent Sediments, Northwest Gulf of Mexico. Symposium for Project 51 of the American Petroleum Institute 1951-1958. American Association of Petroleum Geologists, Tulsa, Oklahoma.

Turner, R.E., and N.N. Rabalais. 1994. Coastal eutrophication near the Mississippi river delta. Nature 368: 619-621.

Turner, R.E., N.N. Rabalais, and D. Justić. 2006. Predicting summer hypoxia in the northern Gulf of Mexico: riverine N, P, and Si loading. Marine Pollution Bulletin 52: 139-148.
Turner, R.E., N.N. Rabalais, and D. Justić. 2008. Gulf of Mexico hypoxia: alternate states and a legacy. Environmental Science and Technology 42: 2323-2327.

Turner, R.E., N.N. Rabalais, and D. Justić. 2011. Predicting summer hypoxia in the northern Gulf of Mexico: redux. Marine Pollution Bulletin 64: 319-324.

Walker, N.D., and N.N. Rabalais. 2006. Relationships among satellite chlorophyll $a$, river inputs and hypoxia on the Louisiana continental shelf, Gulf of Mexico. Estuaries and Coasts 29: 1081-1093.

Wang, L., and D. Justić. 2009. A modeling study of the physical processes affecting the development of seasonal hypoxia over the inner Louisiana-Texas shelf: circulation and stratification. Continental Shelf Research 29: 1464-1476.

Wiseman Jr., W.M.J., and E.J. Kelly. 1994. Salinity variability within the Louisiana Coastal Current during the 1982 flood season. Estuaries 17: 732-739.

Wiseman, W.J., N.N. Rabalais, R.E. Turner, S.P. Dinnel, and A. MacNaughton. 1997. Seasonal and interannual variability within the Louisiana Coastal Current: stratification and hypoxia. Journal of Marine Systems 12: 237-248.

Wiseman, W.J., N.N. Rabalais, R.E. Turner, and D. Justić. 2004. Hypoxia and the physics of the Louisiana Coastal Current, p. 359-372. In J.C.J. Nihoul, P.O. Zavialov, and P.P. Micklin (eds.), Dying and dead seas: climatic versus anthropic causes. NATO Science Series IV Earth and Environmental Sciences Book Series 36.

Wissel, B., Z.J. Quiñones-Rivera, and B. Fry. 2008. Combined analyses of $\mathrm{O}_{2}$ and $\mathrm{CO}_{2}$ for studying the coupling of photosynthesis and respiration in aquatic systems. Canadian Journal of Fisheries and Aquatic Sciences 65: 2378-2388.

Xu, K., C.K. Harris, R.D. Hetland, and J.M. Kaihatu. 2011. Dispersal of Mississippi and Atchafalaya sediment on the Texas-Louisiana shelf: model estimates for the year 1993. Continental Shelf Research 31: $1558-1575$. 